\title{
Delayed Noradrenergic Activation in the Dorsal Hippocampus Promotes the Long-Term Persistence of Extinguished Fear
}

\author{
Ning Chai ${ }^{1,2,7}$, Jian-Feng Liu ${ }^{1,3,7}$, Yan-Xue Xue ${ }^{3,7}$, Chang Yang ${ }^{4}$, Wei Yan ${ }^{1,3}$, Hui-Min Wang ${ }^{1,3}$, Yi-Xiao Luo', \\ Hai-Shui Shi ${ }^{5}$, Ji-Shi Wang ${ }^{4}$, Yan-Ping Bao ${ }^{3}$, Shi-Qiu Meng ${ }^{1,3}$, Zeng-Bo Ding ${ }^{3}$, Xue-Yi Wang*,2 and Lin Lu*, ',3,6 \\ 'Peking University Sixth Hospital/Institute of Mental Health and Key Laboratory of Mental Health, Ministry of Health, Beijing, China; ${ }^{2}$ Institute of \\ Mental Health and Hebei Brain Ageing and Cognitive Neuroscience Laboratory, Hebei Medical University, Shijiazhuang, China; ${ }^{3}$ National \\ Institute on Drug Dependence, Peking University, Beijing, China; ${ }^{4}$ Affiliated Hospital and School of Pharmacy of Guiyang Medical University, \\ Guiyang, China; ${ }^{5}$ Department of Biochemistry and Molecular Biology, Basic Medical College, Hebei Medical University, Shijiazhuang, China; \\ ${ }^{6}$ Peking-Tsinghua Center for Life Sciences and PKU-IDG/McGovern Institute for Brain Research, Peking University, Beijing, China
}

\begin{abstract}
Fear extinction has been extensively studied, but little is known about the molecular processes that underlie the persistence of extinction long-term memory (LTM). We found that microinfusion of norepinephrine (NE) into the CAI area of the dorsal hippocampus during the early phase $(\mathrm{O} h)$ after extinction enhanced extinction LTM at 2 and 14 days after extinction. Intra-CAI infusion of NE during the late phase $(12 \mathrm{~h}$ ) after extinction selectively promoted extinction LTM at 14 days after extinction that was blocked by the $\beta$-receptor antagonist propranolol, protein kinase A (PKA) inhibitor Rp-cAMPS, and protein synthesis inhibitors anisomycin and emetine. The phosphorylation levels of PKA, cyclic adenosine monophosphate response element-binding protein (CREB), GluRI, and the membrane GluRI level were increased by NE during the late phase after extinction that was also blocked by propranolol and Rp-CAMPS. These results suggest that the enhancement of extinction LTM persistence induced by NE requires the activation of the $\beta$-receptor/PKA/CREB signaling pathway and membrane GluRI trafficking. Moreover, extinction increased the phosphorylation levels of ErkI/2, CREB, and GluRI, and the membrane GluRI level during the late phase, and anisomycin/emetine alone disrupted the persistence of extinction LTM, indicating that the persistence of extinction LTM requires late-phase protein synthesis in the CAI. Propranolol and Rp-cAMPS did not completely disrupt the persistence of extinction LTM, suggesting that another $\beta$-receptor/PKA-independent mechanism underlies the persistence of extinction LTM. Altogether, our results showed that enhancing hippocampal noradrenergic activity during the late phase after extinction selectively promotes the persistence of extinction LTM.

Neuropsychopharmacology (2014) 39, 1933-1945; doi:I0.1038/npp.20I4.42; published online I2 March 2014
\end{abstract}

\section{INTRODUCTION}

A novel context (conditioned stimulus (CS)), after being paired with a fearful stimulus (unconditioned stimulus (US)), can alone elicit a fear response. Several hours after conditioning, this fear association is consolidated to become a long-term memory (LTM) (McGaugh, 2000; Mueller and Pilzecker, 1900; Squire and Davis, 1981). Consolidated memory can undergo extinction after repeat exposure to the CS (Herry et al, 2010; Lee et al, 2006; Pavlov, 1927). Extinction is suggested to be a new CS-no US memory but not the erasure of the original CS-US memory because the extinguished fear can be spontaneously

*Correspondence: Professor L Lu, Institute of Mental Health and National Institute on Drug Dependence, Peking University, 51 Huayuanbei Road, Beijing I00191, China, Tel: +86 1082802459 , Fax: +86 10 62032624, E-mail: linlu@bjmu.edu.cn or Professor XY Wang, Institute of Mental Health Hebei Brain Ageing and Cognitive Neuroscience Laboratory, Hebei Medical University, Shijiazhuang 05003।, China, E-mail: ydyywxy@।63.com

${ }^{7}$ The first three authors contributed equally to this work.

Received 29 October 2013; revised 8 February 2014; accepted 10 February 2014; accepted article preview online 19 February 2014 recovered, renewed, or reinstated (Maren et al, 2013; Quirk, 2002). Although extinction memory has been extensively studied, little is known about the cellular and molecular processes that underlie the persistence of extinction LTM.

The hippocampus is one of the most important brain areas that participate in extinction memory (Herry et al, 2010), and plays an important role in integrating contextual information (Maren et al, 2013; Winocur and Gilbert, 1984). It has been suggested to encode contextual specificity to regulate extinction memory (Ji and Maren, 2007; SotresBayon et al, 2012), whereas extinction memory might be encoded in the prefrontal cortex (Milad and Quirk, 2002; Morgan and LeDoux, 1999; Quirk, 2002; Quirk et al, 2006; Quirk et al, 2000). In the contextual fear memory, the hippocampus is involved in the acquisition, consolidation, and retrieval of contextual fear extinction (de Carvalho Myskiw et al, 2013; Kirtley and Thomas, 2010; Szapiro et al, 2003; Vianna et al, 2001).

The formation of LTM requires new protein synthesis (Bourtchouladze et al, 1998; Davis and Squire, 1984; Schafe et al, 1999). The inhibition of protein synthesis during the first few hours after learning results in memory loss $24 \mathrm{~h}$ 
after learning (Abel et al, 1997; Schafe and LeDoux, 2000). Recent evidence suggests that LTM may require other latephase protein and mRNA synthesis $(\sim 12-24 \mathrm{~h}$ after learning) to be persistently stored (Katche et al, 2013; Medina et al, 2008). Disruption of this late-phase process leads to memory loss at 7 days but not 2 days after learning (Bekinschtein et al, 2007; Katche et al, 2010). Because this late-phase process is similar to consolidation, it is referred to as late consolidation (Medina et al, 2008). Several molecules in the hippocampus, including brain-derived neurotrophic factor, extracellular-regulated protein kinases (ERKs), c-fos, and Zif268, are involved in late consolidation (Bekinschtein et al, 2007; Katche et al, 2010; Medina et al, 2008; Rossato et al, 2009). The persistence of LTM can be disrupted by inhibiting the aforementioned signaling pathways or by stress at $12 \mathrm{~h}$ after learning (Yang et al, 2013). The noradrenergic system in the hippocampus also contributes to the late consolidation of fear memory (Katche et al, 2010; Rossato et al, 2009). Norepinephrine (NE) enhances extinction memory that can be blocked by a $\beta$-receptor antagonist (Berlau and McGaugh, 2006; Mueller and Cahill, 2010; Mueller et al, 2008). The main downstream signaling pathway activated by $\mathrm{NE} / \beta$-receptor is the protein kinase A (PKA)/cyclic adenosine monophosphate (cAMP) response element-binding protein (CREB) pathway (Kandel, 2012; Seeds and Gilman, 1971; Vitolo et al, 2002; Zhang et al, 2013). Active PKA also increases the trafficking of AMPA receptor (AMPAR) subunit GluR1 to regulate fear extinction (Matsuo et al, 2008).

The present study tested the effect of NE in the dorsal hippocampus during the late phase after extinction training on the extinguished fear memory. We then determined whether this effect requires new protein synthesis and whether the $\beta$-receptor/PKA/CREB signaling pathway and GluR1 are included in this process. Uncovering the mechanism of extinction LTM persistence will benefit exposure therapy for anxiety-related disorders.

\section{MATERIALS AND METHODS}

\section{Subjects}

Male Sprague-Dawley rats, weighing 220-240 g, were obtained from the Laboratory Animal Center, Peking University Health Science Center. They were housed in groups of five in a temperature-controlled $\left(23 \pm 2{ }^{\circ} \mathrm{C}\right)$ and humiditycontrolled $(50 \pm 5 \%)$ animal facility with free access to food and water. They were kept on a reverse $12 \mathrm{~h} / 12 \mathrm{~h}$ light/dark cycle. All experimental procedures were performed in accordance with the National Institutes of Health Guide for the Care and Use of Laboratory Animals and were approved by the Biomedical Ethics Committee for animal use and protection of Peking University.

\section{Surgery}

The rats (weighing 280-300 g when surgery began) were anesthetized with sodium pentobarbital $(50 \mathrm{mg} / \mathrm{kg}$, i.p.). Guide cannulae (23 gauge; Plastics One, Roanoke, VA) were bilaterally implanted $1 \mathrm{~mm}$ above the CA1 area of the hippocampus (Shi et al, 2012; Zhu et al, 2012). The coordinates were the following: anterior/posterior, $-4.30 \mathrm{~mm}$; medial/lateral, $\pm 2.0 \mathrm{~mm}$; dorsal/ventral, $-2.0 \mathrm{~mm}$ (Paxinos and Watson, 2005). The cannulae were anchored to the skull with stainless-steel screws and dental cement. A stainlesssteel stylet blocker was inserted into each cannula to keep it patent and prevent infection (He et al, 2011; Li et al, 2010). The rats were allowed to recover for at least 1 week after surgery.

\section{Intracranial Injections}

The $\beta$-receptor blocker propranolol, protein synthesis inhibitors anisomycin and emetine, PKA inhibitor Rp-cAMPS, and NE were purchased from Sigma (St Louis, MO). Emetine was dissolved in $10 \%$ dimethylsulfoxide (DMSO), and the other drugs were dissolved in $0.9 \%$ saline. All drugs were freshly prepared before the experiments. The doses of the drugs $(10 \mu \mathrm{g} / \mu \mathrm{l}$ propranolol, $100 \mu \mathrm{g} / \mu \mathrm{l}$ anisomycin, $25 \mu \mathrm{g} / \mu \mathrm{l}$ emetine, $1.0 \mu \mathrm{g} / \mu \mathrm{l} \mathrm{Rp}$-cAMPs, and 0.3 or $1.0 \mu \mathrm{g} / \mu \mathrm{l} \mathrm{NE}$ ) were based on previous studies (LaLumiere et al, 2003; Lima et al, 2009; Moncada et al, 2011). The infusion volume of $\mathrm{NE}$ was $1.0 \mu \mathrm{l}$, and the infusion volume of the other drugs was $0.5 \mu \mathrm{l}$ to minimize the total infusion volume (Katche et al, 2010). The drugs were infused bilaterally over $1 \mathrm{~min}$, and the injection needle was kept in place for an additional $1 \mathrm{~min}$ to allow for drug diffusion (Li et al, 2008; Lu et al, 2005).

\section{Contextual Fear Memory}

Contextual fear conditioning was conducted in four identical isolated shock chambers (Beijing Macro Ambition S\&T Development, Beijing, China). The contextual fear conditioning procedure was modified from previous studies (Lubin and Sweatt, 2007; Yang et al, 2013). The rats were handled for 3 days before conditioning. On the day of the experiments, they were placed into the conditioning chamber and allowed to explore the chamber for $2 \mathrm{~min}$, after which they received an electric footshock $(0.8 \mathrm{~mA}, 1 \mathrm{~s})$. The $2 \mathrm{~min} / 1 \mathrm{~s}$ procedure was repeated a total of three times, and the rats were allowed to explore the conditioning chamber for an additional $1 \mathrm{~min}$. After removing the rat from the chamber, the chamber was cleaned with $75 \%$ alcohol to eliminate any residual odor. The day after the LTM test, the rats were exposed to the training chamber for $30 \mathrm{~min}$ (or $20 \mathrm{~min}$ for weak extinction in experiment 2) without any footshock for extinction. Extinction LTM tests 1 and 2 were separately conducted 2 days and 14 days after extinction. After the second extinction LTM test, one shock was given to reinstate extinguished fear (Haaker et al, 2013). The reinstatement test was conducted $24 \mathrm{~h}$ after the reinstatement footshock. All memory tests were conducted by exposing the rats to the conditioning chamber for $5 \mathrm{~min}$ without footshock. All experimental sessions were videorecorded for offline analysis. Freezing behavior was defined as the lack of all movement, with the exception of respiration.

\section{Elevated Plus Maze}

The elevated plus maze test was based on our previous studies (Suo et al, 2013). Briefly, each rat was first placed in the central zone of the elevated plus maze. The rat was 
allowed to freely explore the maze for $5 \mathrm{~min}$, and the entire test was conducted under dim light conditions. The number of entries into and time (in seconds) spent on the open arms were recorded by two independent observers who were blind to the animal groups and sat quietly $2.5 \mathrm{~m}$ from the maze.

\section{Locomotor Activity Test}

Locomotor activity was measured with an automated video tracking system (DigBehv-LM4, Shanghai Jiliang Software Technology, Shanghai, China) that was used in our previous studies (Sun et al, 2013). A monochrome video camera was mounted on top of each chamber. All chambers were connected to a computer that recorded locomotion. The video files (stored on the computer) were analyzed using DigBehv analysis software. Locomotor activity is expressed as the total distance traveled during the 5 min test.

\section{Western Blot Assays}

The western blot method was based on our previous studies (Ren et al, 2013; Wang et al, 2010; Xue et al, 2012). All rats were decapitated without anesthesia $1 \mathrm{~h}$ after the end of extinction. After decapitation, the brains were rapidly extracted and frozen in $-60{ }^{\circ} \mathrm{C} \mathrm{N}$-hexane. The brains were then transferred to $\mathrm{a}-80{ }^{\circ} \mathrm{C}$ freezer. Bilateral tissue punches (16 gauge) of the CA1 area were placed in a $1.5 \mathrm{ml}$ microtube that contained ice-cold homogenization buffer (0.32 $\mathrm{M}$ sucrose, $4 \mathrm{mM}$ HEPES, $1 \mathrm{mM}$ EDTA, $1 \mathrm{mM}$ EGTA, and protease/phosphatase inhibitors cocktail, $\mathrm{pH}$ 7.4). After being homogenized by an electrical disperser (Wiggenhauser, Sdn Bhd), the homogenate was centrifuged at $1000 \times g$ for $10 \mathrm{~min}$ at $4{ }^{\circ} \mathrm{C}$ to obtain the pellet (P1) that contained nuclei and large debris. The supernatant (S1) was again centrifuged at $10000 \times g$ for $30 \mathrm{~min}$ at $4{ }^{\circ} \mathrm{C}$ to generate a crude synaptosomal fraction (P2) and supernatant (S2). The crude synaptosomal membrane pellet (P2) was lysed hypoosmotically and centrifuged at $25000 \times g$ for $30 \mathrm{~min}$ at $4{ }^{\circ} \mathrm{C}$ to generate the synaptosomal membrane fraction (LP1). LP1 was resuspended in the HEPES-lysis buffer (50 mM HEPES, $1 \mathrm{mM}$ EDTA, $1 \mathrm{mM}$ EGTA, and protease/phosphatase inhibitors cocktail, $\mathrm{pH}$ 7.4). The protein concentrations of all samples (S2 and LP1) were determined using the bicinchoninic acid assay (Beyotime Biotechnology, Jiangsu, China). The samples were further diluted in the HEPES-lysis buffer to equalize the protein concentrations. Protein sample loading buffer (16\% glycerol, $20 \%$ mercaptoethanol, $2 \%$ sodium dodecyl sulfate (SDS), and $0.05 \%$ bromophenol blue) was added to each sample (3:1, sample/loading buffer) before boiling for $3 \mathrm{~min}$. The samples were cooled and subjected to SDS-polyacrylamide gel electrophoresis (10\% acrylamide/ $0.27 \% N, N^{\prime}$-methylenebisacryalamide resolving gel) for $\sim 40 \mathrm{~min}$ at $80 \mathrm{~V}$ in stacking gel and for $\sim 1 \mathrm{~h}$ at $120 \mathrm{~V}$ in resolving gel. The proteins were electrophoretically transferred to Immobilon-P transfer membranes (Millipore, Bedford, MA) at $250 \mathrm{~mA}$ for $2.5 \mathrm{~h}$. The membranes were washed with TBST (Tris-buffered saline plus $0.05 \%$ Tween-20, $\mathrm{pH} 7.4$ ) and then dipped in blocking buffer ( $5 \%$ bovine serum albumin (BSA) in TBST) overnight at $4{ }^{\circ} \mathrm{C}$. The next day, the membranes were incubated for $1 \mathrm{~h}$ at room temperature on an orbital shaker with anti-pPKA antibody, anti-PKA antibody, anti-Erk1/2 antibody, antipErk1/2 antibody, anti-pCREB antibody, anti-CREB antibody, anti-GluR1 antibody (1:200; Santa Cruz Biotechnology, Santa Cruz, CA), anti-pGluR1 antibody (1:1000; Epitomics (an Abcam company), Burlingame, CA), or anti- $\beta$-actin antibody (1:1000; Santa Cruz Biotechnology) in TBST plus $5 \%$ BSA. After three 5-min washes in TBST buffer, the blots were incubated for $45 \mathrm{~min}$ at room temperature on a shaker with horseradish peroxidase-conjugated secondary antibody (goat anti-mouse IgG for $\beta$-actin and GluR1 and goat anti-rabbit IgG for the others; Santa Cruz Biotechnology) diluted 1:5000 in blocking buffer. The blots were then washed three times for $5 \mathrm{~min}$ each in TBST and incubated with a layer of Super Signal Enhanced chemiluminescence substrate (detection reagents 1 and 2, 1:1 ratio, Applygen Technologies, Beijing, China). Excess mixture was dripped off before the blots were wrapped with a clean piece of plastic wrap (no bubbles between blot and wrap), and then the blots were exposed to X-ray film (Eastman Kodak Company) for 5-60 s. Band intensities were quantified using Quantity One software (version 4.4.0, Bio-Rad, Hercules, CA).

\section{Experimental Design}

Experiment 1: effect of NE microinfused into the CA1 after extinction on extinction memory. To assess the effect of $\mathrm{NE}$ treatment in the CA1 of the dorsal hippocampus on extinction memory, at 1 day after the long-term contextual fear test, rats (12 groups, $n=8-10$ per group) were separated into three treatment doses for four time points $(0,6,12$, and $24 \mathrm{~h}$ ) after extinction. Different groups of rats were microinfused with $0,0.3$, or $1.0 \mu \mathrm{g} / \mu \mathrm{l}$ per side at different times after extinction, respectively. All rats then underwent following memory tests (Figure 1a).

Experiment 2: distinct effects of NE microinfused into the $C A 1$ at 0 and $12 \mathrm{~h}$ after short-term extinction on extinction memory. To assess the differential roles of $\mathrm{NE}$ treatment in the CA1 area of the dorsal hippocampus at 0 and $12 \mathrm{~h}$ after extinction on extinction memory, short-term extinction training (only $20 \mathrm{~min}$ ) at 2 days after fear conditioning was performed to obtain weak extinction memory. The $1.0 \mu \mathrm{g} / \mu \mathrm{l}$ dose of $\mathrm{NE}$ was used in the subsequent experiments based on the results of experiment 1 . Three groups of rats ( $n=8-10$ per group) were used: (1) the rats underwent extinction without treatment (Control group), (2) the rats received $\mathrm{NE}(1.0 \mu \mathrm{g} / \mu \mathrm{l}$ per side) into the CA1 at $0 \mathrm{~h}$ after extinction ( $0 \mathrm{~h}$ NE group), and (3) the rats received $\mathrm{NE}(1.0 \mu \mathrm{g} / \mu \mathrm{l}$ per side) into the CA1 at $12 \mathrm{~h}$ after extinction (12 $\mathrm{h}$ NE group). All rats then underwent following memory tests (Figure 2a).

Experiment 3: effect of NE microinfused into the CA1 after extinction on anxiety-like behavior and locomotion. To determine whether NE microinfused into the CA1 after extinction can alter anxiety-like behavior or locomotor activity, the elevated plus maze test and locomotor activity test were performed. Two separate groups of rats $(n=9-10$ per group) were microinfused with saline $(1.0 \mu \mathrm{l}$ per side) or $\mathrm{NE}(1.0 \mu \mathrm{g} / \mu \mathrm{l}$ per side) into the CA1 at $12 \mathrm{~h}$ after extinction. 
a

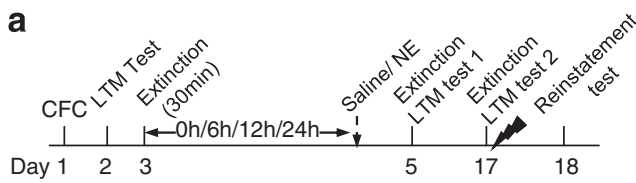

b

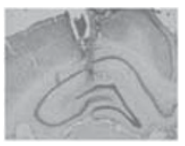

C

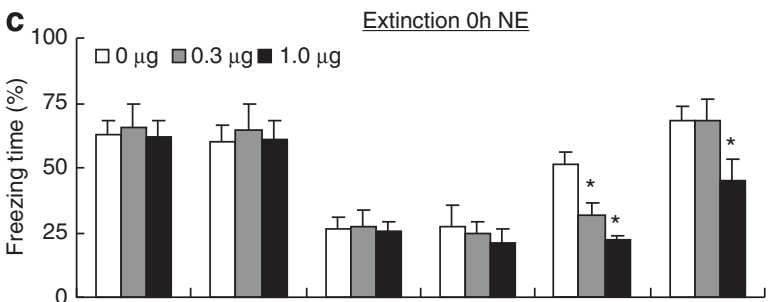

d $100 \quad$ Extinction $6 \mathrm{~h} \mathrm{NE}$
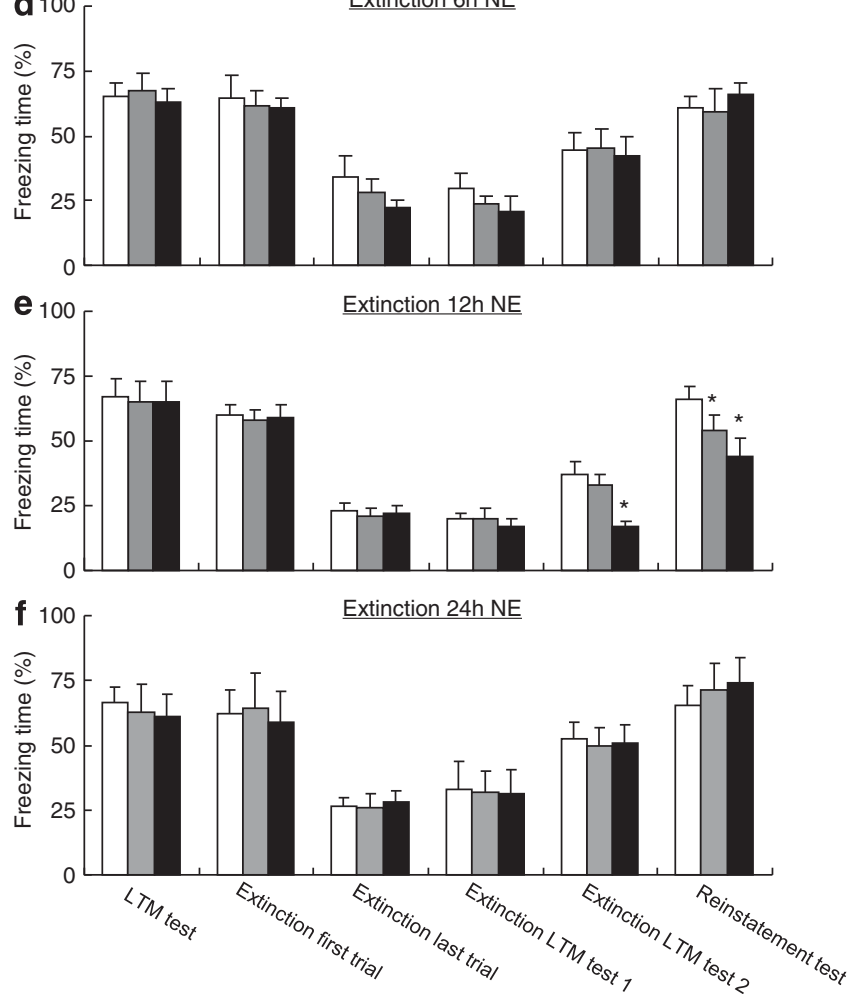

Figure I Norepinephrine in the CAI during the early or late phase after extinction enhanced extinction memory. (a) Timeline for this experiment. Norepinephrine was microinfused into the CAI subarea of the dorsal hippocampus at 0, 6, 12, and 24h after extinction. Extinction memory was tested 2 and 14 days later. After the second extinction LTM test, a footshock (0.8 mA, I s) was given, and fear reinstatement was tested I day later. (b) Representative cannula placement in the CAI of rat. (c) Norepinephrine at doses of 0.3 and $1.0 \mu \mathrm{g} / \mu \mathrm{l}$ microinfused into the CAI at $\mathrm{O}$ h after extinction enhanced the extinction LTM test 14 days after extinction (both $p<0.05$ ), and NE at a dose of $1.0 \mu \mathrm{g} / \mu \mathrm{l}$ inhibited the reinstatement test $(p<0.05)$. (d) Norepinephrine microinfused into the CAl at $6 \mathrm{~h}$ after extinction did not affect the extinction LTM test or reinstatement test. (e) Norepinephrine at $1.0 \mu \mathrm{g} / \mu \mathrm{l}$ microinfused into the $\mathrm{CAl}$ at $12 \mathrm{~h}$ after extinction enhanced the extinction LTM test 14 days later and NE at a dose of 0.3 and $1.0 \mu \mathrm{g} / \mu \mathrm{l}$ reduced the subsequent reinstatement test (all $p<0.05$ ). (f) Norepinephrine microinfused into the $\mathrm{CAl}$ at $24 \mathrm{~h}$ after extinction had no effect on the subsequent extinction LTM test or reinstatement test. The data are expressed as mean \pm SEM ( $n=8-10$ per group). ${ }^{*} P<0.05$, compared with $0 \mu \mathrm{g}$ NE group. CFC, contextual fear conditioning; LTM, long-term memory; NE, norepinephrine.

The elevated plus maze test and locomotor activity test were performed 14 days after extinction, consistent with the second extinction LTM test in the other experiments. a
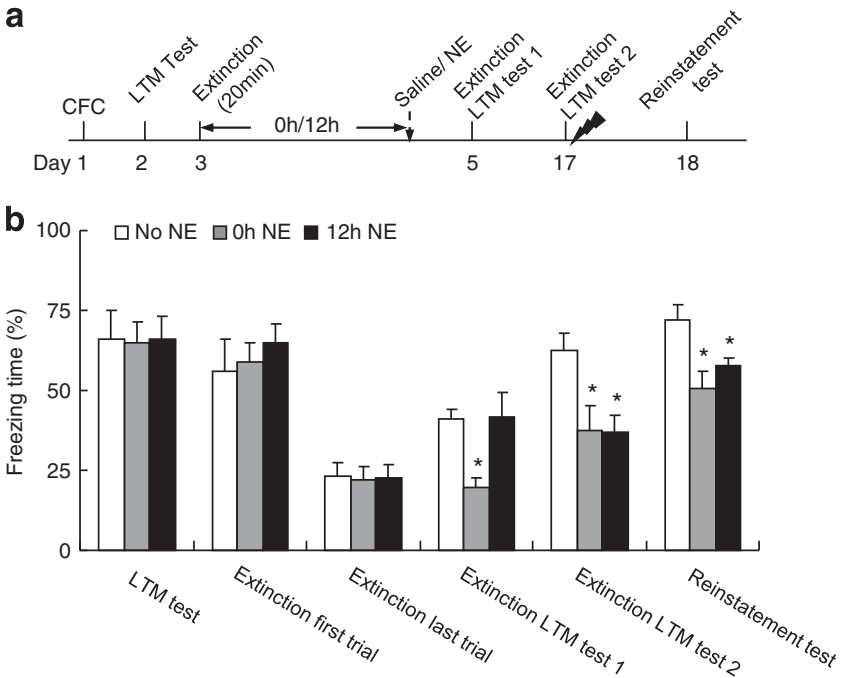

Figure 2 Norepinephrine in the CAI during the late phase after extinction selectively enhanced the persistence of extinction LTM. (a) Timeline for this experiment. Norepinephrine $(1.0 \mu \mathrm{g} / \mu \mathrm{l})$ was microinfused into the $\mathrm{CAl}$ at 0 or $12 \mathrm{~h}$ after weak extinction training (only $20 \mathrm{~min}$ ). Extinction LTM was tested 2 or 14 days later. After the extinction LTM test 2, a footshock ( $0.8 \mathrm{~mA}, \mathrm{I}$ ) was given, and fear reinstatement was tested I day later. A separate group without any drug treatment was used as a control. (b) At 2 days after weak extinction, compared with No NE group, the $0 \mathrm{~h}$ NE $(p<0.05)$ but not 12 h NE $(p>0.05)$ group of rats showed reduced freezing time, and both the $\mathrm{Oh}$ NE group and $12 \mathrm{~h} \mathrm{NE}$ group exhibited lower fear in extinction LTM test 2 and reinstatement test (all $p<0.05$ ). These results suggest that $\mathrm{NE}$ microinfused into the $\mathrm{CAl}$ at $\mathrm{Oh}$ after extinction enhanced the formation of extinction LTM, whereas NE treatment $12 \mathrm{~h}$ after extinction selectively promoted the persistence of extinction LTM. The data are expressed as mean \pm SEM $(n=8-10$ per group). ${ }^{*} P<0.05$, compared with control group.

Experiment 4: effect of $\beta$-receptor inhibitor on $N E-$ induced enhancement of extinction LTM persistence. To test whether the effect of NE microinfused into the CA1 on the persistence of extinction LTM requires $\beta$-receptor activation, the $\beta$-receptor antagonist propranolol or saline was infused $30 \mathrm{~min}$ before NE microinfusion. Four separate groups of rats were used ( $n=10-11$ per group): (1) the rats were microinfused with saline $(0.5 \mu \mathrm{l}$ per side) into the CA1 at $11.5 \mathrm{~h}$ after extinction and then with saline $(1.0 \mu \mathrm{l}$ per side) 30 min later (Saline + Saline group), (2) the rats were microinfused with saline $(0.5 \mu \mathrm{l}$ per side) into the CA1 at $11.5 \mathrm{~h}$ after extinction and then with NE $(1.0 \mu \mathrm{g} / \mu \mathrm{l}$ per side) 30 min later (Saline + NE group), (3) the rats were microinfused with propranolol (10-11 $\mu \mathrm{g} / 0.5 \mu \mathrm{l}$ per side) into the $\mathrm{CA} 1$ at $11.5 \mathrm{~h}$ after extinction and then with saline $(1.0 \mu \mathrm{l}$ per side) $30 \mathrm{~min}$ later (Propranolol + Saline group), and (4) the rats were microinfused with propranolol $(1.0 \mu \mathrm{g} / 0.5 \mu \mathrm{l}$ per side) into the CA1 at $11.5 \mathrm{~h}$ after extinction and then with NE $(1.0 \mu \mathrm{g} / \mu \mathrm{l}$ per side) $30 \mathrm{~min}$ later (Propranolol $+\mathrm{NE}$ group). All rats then underwent following memory tests (Figure 4a).

Experiment 5: effect of PKA inhibitor on NE-induced enhancement of extinction LTM persistence. This experiment assessed the effect of PKA inhibition on the enhanced extinction LTM persistence induced by NE. The 
PKA inhibitor Rp-cAMPS or saline was microinfused into the CA1 area 30 min before NE microinfusion. Four separate groups of rats were used ( $n=8$ per group): (1) the rats were microinfused with saline $(0.5 \mu \mathrm{l}$ per side) into the CA1 $11.5 \mathrm{~h}$ after extinction and then with saline $(1.0 \mu \mathrm{l}$ per side) $30 \mathrm{~min}$ later (Saline + Saline group), (2) the rats were microinfused with saline $(0.5 \mu \mathrm{l}$ per side) into the CA1 $11.5 \mathrm{~h}$ after extinction and then with $\mathrm{NE}(1.0 \mu \mathrm{g} / \mu \mathrm{l}$ per side) $30 \mathrm{~min}$ later (Saline + NE group), (3) the rats were microinfused with Rp-cAMPS $(0.5 \mu \mathrm{g} / 0.5 \mu \mathrm{l}$ per side) into the CA1 $11.5 \mathrm{~h}$ after extinction and then with saline $(1.0 \mu \mathrm{l}$ per side) $30 \mathrm{~min}$ later (Rp-cAMPS + Saline group), and (4) the rats were microinfused with Rp-cAMPS $(0.5 \mu \mathrm{g} / 0.5 \mu \mathrm{l}$ per side $)$ into the CA1 $11.5 \mathrm{~h}$ after extinction and then with NE $(1.0 \mu \mathrm{g} / \mu \mathrm{l}$ per side $)$ 30 min later (Rp-cAMPS + NE group). All rats then underwent following memory tests (Figure 5a).

Experiment 6: effect of protein synthesis inhibitor on NEinduced enhancement of extinction LTM persistence. This experiment tested whether the enhanced extinction LTM persistence induced by NE requires new protein synthesis. The protein synthesis inhibitor anisomycin was microinfused into the CA1 area $30 \mathrm{~min}$ before NE microinfusion. Four separate groups of rats were used $(n=8-10$ per group): (1) the rats were microinfused with saline $(0.5 \mu \mathrm{l}$ per side) into the CA1 at $11.5 \mathrm{~h}$ after extinction and then with saline $(1.0 \mu \mathrm{l}$ per side) $30 \mathrm{~min}$ later (Saline + Saline group), (2) the rats were microinfused with saline $(0.5 \mu \mathrm{l}$ per side) into the CA1 at $11.5 \mathrm{~h}$ after extinction and then with NE $(1.0 \mu \mathrm{g} / \mu \mathrm{l}$ per side) $30 \mathrm{~min}$ later (Saline $+\mathrm{NE}$ group), (3) the rats were microinfused with anisomycin $(80 \mu \mathrm{g} / 0.8 \mu \mathrm{l}$ per side) into the CA1 at $11.5 \mathrm{~h}$ after extinction and then with saline ( $1.0 \mu \mathrm{l}$ per side) $30 \mathrm{~min}$ later (Anisomycin + Saline group), and (4) the rats were microinfused with anisomycin $(80 \mu \mathrm{g} / 0.8 \mu \mathrm{l}$ per side) into the CA1 at $11.5 \mathrm{~h}$ after extinction and then with NE $(1.0 \mu \mathrm{g} / \mu \mathrm{l}$ per side) $30 \mathrm{~min}$ later (Anisomycin $+\mathrm{NE}$ group). All rats then underwent following memory tests. The protein synthesis inhibitor emetine was microinfused into the CA1 area $30 \mathrm{~min}$ before NE microinfusion. Four separate groups of rats were used $(n=10$ per group): DMSO + Saline group; $\mathrm{DMSO}+\mathrm{NE}$ group; Emetine + Saline group; and Emetine $+\mathrm{NE}$ group (Figure 6a).

Experiment 7: effect of NE microinfused into the CA1 on the $\beta$-receptor/PKA signaling pathway. In this experiment, we tested whether NE microinfused into the CA1 area at $12 \mathrm{~h}$ after extinction alters the expression of pPKA, pErk1/2, pCREB, and pGluR1 (Ser 845, a site phosphorylated by PKA) and membrane expression of GluR1 in the CA1 area. Five groups of rats were used ( $n=8$ per group): (1) the rats were microinfused with saline $(1.5 \mu$ l per side) into the CA1 without extinction (No extinction, Saline+ Saline group), (2) the rats were microinfused with saline $(0.5 \mu \mathrm{l}$ per side) into the CA1 at $11.5 \mathrm{~h}$ after extinction and then with saline $(1.0 \mu \mathrm{l}$ per side) $30 \mathrm{~min}$ later (Saline+ Saline group), (3) the rats were microinfused with saline $(0.5 \mu \mathrm{l}$ per side) into the CA1 at $11.5 \mathrm{~h}$ after extinction and then with NE $(1.0 \mu \mathrm{g} / \mu \mathrm{l}$ per side) $30 \mathrm{~min}$ later (Saline $+\mathrm{NE}$ group), (4) the rats were microinfused with propranolol $(1.0 \mu \mathrm{g} / 0.5 \mu \mathrm{l}$ per side) into the CA1 at $11.5 \mathrm{~h}$ after extinction and then with $\mathrm{NE}(1.0 \mu \mathrm{g} / \mu \mathrm{l}$ per side $) 30 \mathrm{~min}$ later (Propranolol + NE group), and (5) the rats were microinfused with Rp-cAMPS $(0.5 \mu \mathrm{g} / 0.5 \mu \mathrm{l}$ per side) into the CA1 at $11.5 \mathrm{~h}$ after extinction and then with $\mathrm{NE}(1.0 \mu \mathrm{g} / \mu \mathrm{l}$ per side) 30 min later ( $\mathrm{Rp}$-cAMPS + NE group). The rats were decapitated $13 \mathrm{~h}$ after extinction ( $1 \mathrm{~h}$ after the NE infusion).

\section{Statistical Analysis}

The data are expressed as mean \pm SEM. The statistical analyses were performed using SAS 9.2 software. One-way analysis of variance (ANOVA) was performed to analyze the elevated plus maze and western blot results. To analyze extinction LTM, repeated-measures ANOVA was performed, with Test (last trial of extinction, extinction LTM test 1, extinction LTM test 2, and reinstatement test) as the within-subjects factor (the between-subjects factors are stated in the Results section). The post hoc analyses of significant effects in the ANOVAs were performed using the Least Square Means test. Values of $p<0.05$ were considered statistically significant.

\section{RESULTS}

NE in the CA1 Area during the Early or Late Phase after Extinction Enhanced Extinction Memory

In experiment 1 , we tested the effect of $\mathrm{NE}$ microinfused into the CA1 at different time points $(0,6,12$, and $24 \mathrm{~h})$ after extinction on extinction memory. For each time point $(0,6$, 12 , and $24 \mathrm{~h}$ ) after extinction, no significant effects of groups $(0,0.3$, and $1.0 \mu \mathrm{g} \mathrm{NE})$ were observed in the LTM test, the first trial of extinction, and the last trial of extinction (all $p>0.05)$. For each time point $(0,6,12$, and $24 \mathrm{~h}$ ) after extinction, the two-way repeated-measures ANOVA, with Test as the within-subjects factor and Dose $(0,0.3$, and $1.0 \mu \mathrm{g} \mathrm{NE})$ as the between-subjects factor, was conducted to analyze the extinction LTM, separately.

For NE administration at $0 \mathrm{~h}$ after extinction, the ANOVA revealed significant effects of Test $\left(\mathrm{F}_{3,14}=32.96, p<0.01\right)$ and a Test $\times$ Dose interaction $\left(\mathrm{F}_{6,14}=2.66, p<0.05\right)$ but no effect of Dose $\left(\mathrm{F}_{2,14}=0.78, p=0.53\right)$. The post hoc analysis revealed that the 0.3 and $1.0 \mu \mathrm{g}$ NE groups of rats exhibited decreased freezing time in extinction LTM test $2(0.3 \mu \mathrm{g} \mathrm{NE}$ : $t=2.90, p<0.01 ; 1.0 \mu \mathrm{g} \mathrm{NE}: t=4.21, p<0.01)$, and the $1.0 \mu \mathrm{g}$ $\mathrm{NE}$ group of rats exhibited reduced freezing time in the reinstatement test $(0.3 \mu \mathrm{g}$ NE: $t=0.31, p=0.76 ; 1.0 \mu \mathrm{g}$ NE: $t=3.49, p<0.01)$ compared with the $0 \mu \mathrm{g}$ NE group of rats. Moreover, the $0 \mu \mathrm{g}$ NE group of rats exhibited increased freezing time in extinction LTM test 2 (spontaneous recovery) compared with the last trial of extinction $(0 \mu \mathrm{g}$ $\mathrm{NE}: t=3.60, p<0.01 ; 0.3 \mu \mathrm{g}$ NE: $t=0.83, p=0.41 ; 1.0 \mu \mathrm{g} \mathrm{NE}:$ $t=0.56, p=0.58)$. However, all groups of rats exhibited increased freezing time in the reinstatement test compared with extinction LTM test $2(0 \mu \mathrm{g}$ NE: $t=2.33, p<0.05 ; 0.3 \mu \mathrm{g}$ NE: $t=5.12, p<0.01 ; 1.0 \mu \mathrm{g}$ NE: $t=3.20, p<0.01)$, indicating that the original memory was not erased in any of the groups of rats (Figure 1c).

For NE administration at $6 \mathrm{~h}$ after extinction, the ANOVA revealed a significant effect of Test $\left(\mathrm{F}_{3,14}=21.69, p<0.01\right)$ but no effect of Dose $\left(\mathrm{F}_{2,14}=1.14, p=0.43\right)$ and no Test $\times$ Dose interaction $\left(\mathrm{F}_{6,14}=0.39, p=0.88\right.$; Figure $\left.1 \mathrm{~d}\right)$. 
For NE administration at $12 \mathrm{~h}$ after extinction, the ANOVA revealed a significant effect of Test $\left(\mathrm{F}_{3,14}=53.46\right.$, $p<0.01)$ and a Test $\times$ Dose interaction $\left(\mathrm{F}_{6,14}=2.30\right.$, $p<0.05)$ but no effect of Dose $\left(\mathrm{F}_{2,14}=1.15, p=0.43\right)$. The post hoc analysis revealed that the $1.0 \mu \mathrm{g}$ NE group of rats exhibited reduced freezing time in extinction LTM test 2 $(0.3 \mu \mathrm{g}$ NE: $t=0.80, p=0.42 ; 1.0 \mu \mathrm{g}$ NE: $t=3.77, p<0.01)$, and the 0.3 and $1.0 \mu \mathrm{g}$ NE groups of rats exhibited reduced freezing time in the reinstatement test $(0.3 \mu \mathrm{g} \mathrm{NE}: t=2.07$, $p<0.05 ; 1.0 \mu \mathrm{g}$ NE: $t=3.96, p<0.01)$ compared with the $0 \mu \mathrm{g} \mathrm{NE}$ group of rats. Only the fear response in the $1.0 \mu \mathrm{g}$ $\mathrm{NE}$ group of rats did not spontaneously recover $(0 \mu \mathrm{g} \mathrm{NE}$ $t=3.20, p<0.01 ; 0.3 \mu \mathrm{g}$ NE: $t=2.30, p<0.05 ; 1.0 \mu \mathrm{g} \mathrm{NE}:$ $t=0.09, \quad p=0.93)$. Moreover, the fear response was reinstated in all groups of rats $(0 \mu \mathrm{g} \mathrm{NE}: t=5.22, p<0.01$; $0.3 \mu \mathrm{g} \mathrm{NE}: t=3.96, p<0.01 ; 1.0 \mu \mathrm{g} \mathrm{NE}: t=5.03, p<0.01$; Figure 1e).

For NE administration at $24 \mathrm{~h}$ after extinction, the ANOVA revealed a significant effect of Test $\left(\mathrm{F}_{3,14}=19.75\right.$, $p<0.01)$ but no effect of Dose $\left(\mathrm{F}_{2,14}=1.00, p=0.46\right)$ and no Test $\times$ Dose interaction $\left(F_{6,14}=0.10, p=0.97\right.$; Figure $\left.1 \mathrm{f}\right)$.

Altogether, these results indicate that NE microinfused into the CA1 area at 0 and $12 \mathrm{~h}$, but not at 6 or $24 \mathrm{~h}$, after extinction significantly enhanced extinction memory, reducing the spontaneous recovery and reinstatement of extinguished fear.

\section{NE in the CA1 Area during the Late Phase after Extinction Selectively Enhanced the Persistence of Extinction LTM}

The findings that NE treatment at both 0 and $12 \mathrm{~h}$ after extinction enhanced extinction memory prompted us to explore the potentially distinct roles of NE at these two time points on fear extinction. In experiment 2, we tested the differential roles of $\mathrm{NE}$ microinfused into the CA1 area during the early phase $(0 \mathrm{~h})$ and late phase $(12 \mathrm{~h})$ after weak extinction $(20 \mathrm{~min})$ on extinction memory. The ANOVA revealed no significant effects of the different treatments (No NE, $0 \mathrm{~h} \mathrm{NE}$, and $12 \mathrm{~h} \mathrm{NE}$ ) in the LTM test and the first trial of extinction, and the last trial of extinction (all $p>0.05)$. A two-way repeated-measures ANOVA, with Test as the within-subjects factor and Group (No NE, $0 \mathrm{~h} \mathrm{NE}$, and $12 \mathrm{~h} \mathrm{NE}$ ) as the between-subjects factor, was conducted to analyze extinction LTM, revealing a significant effect of Test $\left(\mathrm{F}_{3,14}=28.19, p<0.01\right)$ and a Test $\times$ Group interaction $\left(\mathrm{F}_{6,14}=2.32, p<0.05\right)$ but no effect of Group $\left(\mathrm{F}_{2,14}=0.25\right.$, $p=0.80)$. The post hoc analysis revealed that compared with the No NE group of rats, the $0 \mathrm{~h}$ NE group of rats exhibited enhanced extinction in extinction LTM test $1(t=2.89$, $p<0.01)$ and extinction LTM test $2(t=3.14, p<0.01)$, and the $12 \mathrm{~h}$ NE group of rats exhibited enhanced extinction in extinction LTM test $2(t=3.49, p<0.01)$ but not extinction LTM test $1(t=0.00, p=1.00)$. These results suggest that in the weak extinction protocol, NE treatment at $0 \mathrm{~h}$ but not at $12 \mathrm{~h}$ after extinction promoted the formation of extinction LTM (tested 2 days after extinction). Fear responses were decreased in the $0 \mathrm{~h} \mathrm{NE}$ group of rats $(t=2.92, p<0.01)$ and $12 \mathrm{~h} \mathrm{NE}$ group of rats $(t=2.02, p<0.05)$ compared with the No NE group of rats in the reinstatement test. Moreover, the fear response was reinstated in the $12 \mathrm{~h}$ NE group of rats $(t=2.91, p<0.01)$ and nearly reinstated in the $0 \mathrm{~h}$ NE group of rats $(t=1.86, p=0.07)$ compared with the last trial of extinction (Figure $2 \mathrm{~b}$ ). Altogether, these results suggest that $\mathrm{NE}$ infusion into the CA1 area during the early phase after extinction enhanced the formation of extinction LTM (tested 2 days after extinction) but selectively enhanced the persistence of extinction LTM (tested 14 days after extinction) during the late phase after extinction (Bekinschtein et al, 2007).

NE in the CA1 during the Late Phase after Extinction Had No Effect on Anxiety-Like Behavior or Locomotion

In experiment 3, we tested whether the enhancement of extinction LTM persistence induced by NE treatment in the CA1 during the late phase after extinction was attributable to alterations in anxiety-like behavior or locomotion. Behavioral tests were performed 14 days after extinction, similar to the second extinction LTM test in the other experiments. For the elevated plus maze test, the one-way ANOVA showed no effects on entries into the open arms $\left(F_{1,18}=0.21, p=0.65\right)$, entries into the closed arms $\left(F_{1,18}=0.25, p=0.62\right)$, or time spent on the open arms $\left(\mathrm{F}_{1,18}=0.11, p=0.74\right.$; Figure $\left.3 \mathrm{a}\right)$. For the locomotor activity test, the two-way repeated-measures ANOVA, with Test (every $\min$ in the test) as the within-subject factor and Group (saline and NE) as the between-subjects factor, showed no significant effects of Group $\left(\mathrm{F}_{1,17}=0.04, p=0.84\right)$ and no Test $\times$ Group interaction $\left(F_{1,17}=0.22, p=0.65\right.$; Figure $\left.3 b\right)$. These results indicate that NE treatment in the CA1 during the late phase after extinction had no effect on anxiety-like behavior or locomotion in rats.

\section{Propranolol Blocked the NE-Induced Enhancement of Extinction LTM Persistence}

In experiment 4 , we tested whether $\beta$-receptor inhibition can block the NE-induced enhancement of extinction LTM persistence. No difference was found between groups (Saline + Saline, Saline + NE, Propranolol + Saline, and Propranolol $+\mathrm{NE}$ ) in the LTM test, the first trial of extinction, or the last trial of extinction (all $p>0.05$ ). The two-way repeated-measures ANOVA, with Propranolol (saline and propranolol) and NE (saline and NE) as the between-subjects factors and Test as the within-subjects factor, was conducted to analyze extinction LTM. The ANOVA showed significant effects of Test $\left(\mathrm{F}_{3,52}=123.35\right.$, $p<0.01)$, NE $\left(\mathrm{F}_{1,52}=5.96, p<0.05\right)$, and Propranolol $\left(\mathrm{F}_{1,52}=7.84, p<0.01\right)$ and a Test $\times \mathrm{NE} \times$ Propranolol interaction $\left(F_{3,52}=3.48, p<0.05\right)$. Follow-up comparisons revealed that compared with Saline $+\mathrm{NE}$ group, Propranolol $+\mathrm{NE}$ group exhibited increased freezing in both extinction LTM test $2(t=3.95, p<0.01)$ and the reinstatement test $(t=5.17, p<0.01)$. Propranolol treatment alone did not affect freezing time in extinction LTM test 2 $(t=1.80, p=0.08)$ or in the reinstatement test $(t=0.67$, $p=0.51$; Figure $4 \mathrm{~b}$ ). Altogether, these results indicate that $\beta$-receptor inhibition blocked the enhancement of extinction LTM persistence induced by NE treatment in the CA1 during the late phase after extinction. 

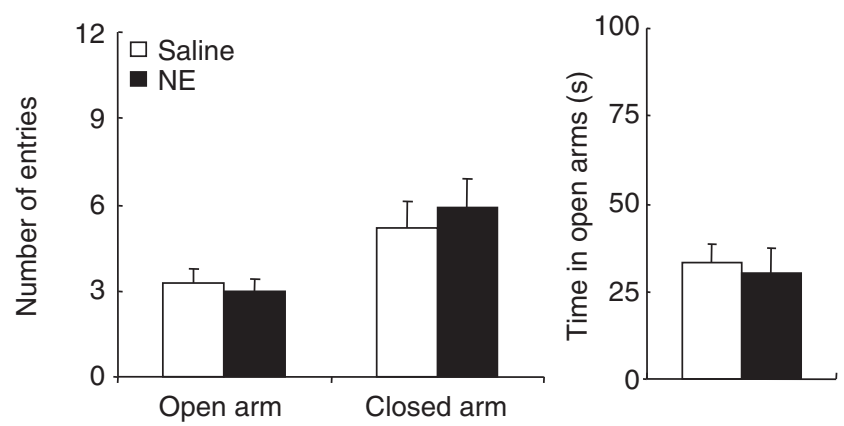

b

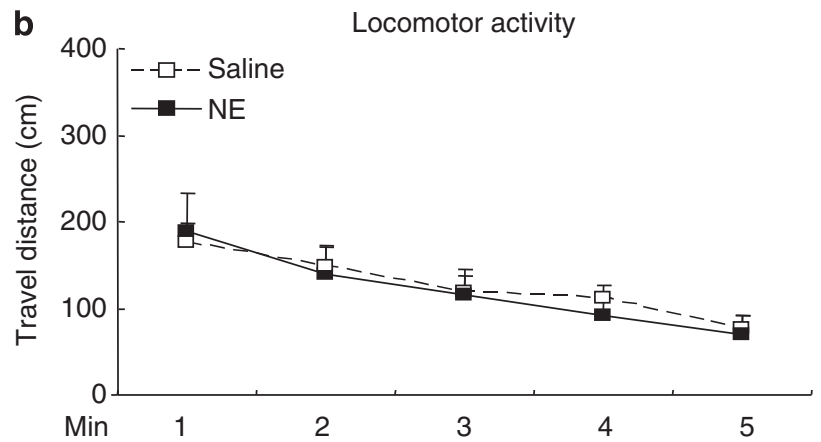

Figure 3 Norepinephrine in the CAI during the late phase after extinction had no effect on anxiety-like behavior or locomotion. (a) At 14 days after NE (I.0 $\mu \mathrm{g} / \mu \mathrm{l})$ microinfusion into the CAI, the rats underwent elevated plus maze test and locomotor activity test. Norepinephrine did not affect the numbers of entries into or time spent on the open arms in the elevated plus maze (all $p>0.05$ ). (b) Norepinephrine did not affect the total distance traveled in the locomotor activity test $(p>0.05)$. The data are expressed as mean \pm SEM ( $n=9-10$ per group).

\section{Rp-cAMPS Blocked the NE-Induced Enhancement of Extinction LTM Persistence}

In experiment 5, we tested whether the PKA inhibitor RpcAMPS can block the NE-induced enhancement of extinction LTM persistence. No difference was found between groups (Saline + Saline, Saline + NE, Rp-cAMPS + Saline, and Rp-cAMPS + NE) in the LTM test, the first trial of extinction, or the last trial of extinction (all $p>0.05$ ). The two-way repeated-measures ANOVA, with Rp-cAMPS (saline and Rp-cAMPS) and NE (saline and NE) as the between-subjects factor and Test as the within-subjects factor, was conducted to analyze extinction LTM. The ANOVA revealed significant effects of Test $\left(\mathrm{F}_{3,43}=105.33\right.$, $p<0.01)$ and $\mathrm{NE}\left(\mathrm{F}_{1,43}=4.65, p<0.05\right)$, a Test $\times \mathrm{NE} \times \mathrm{Rp}-$ cAMPS interaction $\left(\mathrm{F}_{3,43}=2.99, p<0.05\right)$, and a trend toward a significant effect of Rp-cAMPS $\left(\mathrm{F}_{1,43}=3.69\right.$, $p=0.06$ ). Follow-up comparisons revealed that Rp-cAMPS treatment alone did not affect freezing time in extinction LTM test $2(t=0.67, p=0.50)$ or the reinstatement test $(t=0.34, p=0.73)$. However, compared with Saline $+\mathrm{NE}$ group, Rp-cAMPS + NE group exhibited increased freezing in extinction LTM test $2(t=5.10, p<0.01)$ and the reinstatement test $(t=1.95, p=0.05$; Figure $5 \mathrm{~b})$. Altogether, these results indicate that the PKA inhibitor blocked the enhancement of extinction LTM persistence induced by NE treatment in the CA1 during the late phase after extinction. a
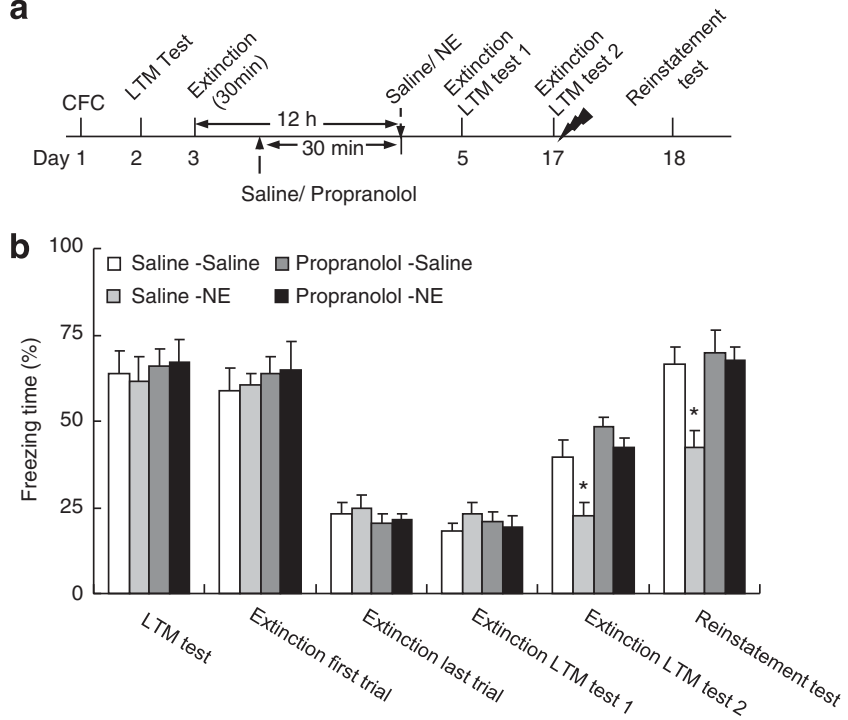

Figure 4 Propranolol blocked the NE-induced enhancement of extinction LTM persistence. (a) Timeline for this experiment. Norepinephrine $(1.0 \mu \mathrm{g} / \mu \mathrm{l})$ was microinfused into the CAI at I $2 \mathrm{~h}$ after extinction training, and the $\beta$-receptor blocker propranolol was microinfused into the CAI 30 min before. Extinction LTM was tested 2 or 14 days later. After the extinction LTM test 2, a footshock $(0.8 \mathrm{~mA}, 1 \mathrm{~s})$ was given, and fear reinstatement was tested I day later. (b) Norepinephrine microinfused into the CAI at $12 \mathrm{~h}$ after extinction enhanced the extinction LTM test 14 days after extinction and the reinstatement test $(p<0.05)$ that were blocked by propranolol $(p<0.05)$. Propranolol microinfused alone did not affect the extinction LTM test or reinstatement test (both $p>0.05$ ). The data are expressed as mean \pm SEM ( $n=10-11$ per group). ${ }^{*} P<0.05$ compared with Saline + Saline group.

\section{Persistence of Extinction LTM Requires Late-Phase Protein Synthesis in the CA1}

In experiment 6 , we tested whether the protein synthesis inhibitors anisomycin and emetine can block the NEinduced enhancement of the persistence of extinction LTM. No difference was found between groups (Saline + Saline, Saline + NE, Anisomycin + Saline, and Anisomycin + NE) in the LTM test, the first trial of extinction, or the last trial of extinction (all $p>0.05$ ). The two-way repeated-measures ANOVA, with Anisomycin (saline and anisomycin) and NE (saline and NE) as the between-subjects factor and Test as the within-subjects factor, was conducted to analyze extinction LTM. The ANOVA showed significant effects of Test $\left(\mathrm{F}_{3,46}=96.71, p<0.01\right)$, NE $\left(\mathrm{F}_{1,46}=22.26, p<0.01\right)$, Anisomycin $\left(\mathrm{F}_{1,46}=16.57, p<0.01\right)$, and a Test $\times \mathrm{NE} \times$ Anisomycin interaction $\left(\mathrm{F}_{3,46}=3.98, p=0.01\right)$. Follow-up comparisons revealed that anisomycin treatment alone increased freezing time in extinction LTM test $2(t=2.19$, $p<0.05)$ and completely blocked the NE-induced decrease in freezing in extinction LTM test $2(t=6.47, p<0.01)$ and the reinstatement test $(t=3.68, p<0.01$; Figure 6b). Furthermore, another protein synthesis inhibitor, emetine, also blocked the persistence of extinction LTM and prevented the extinction-enhancing effect of NE (all $p<0.05$; Figure 6c). Altogether, these results indicate that not only the enhancement of extinction LTM persistence 

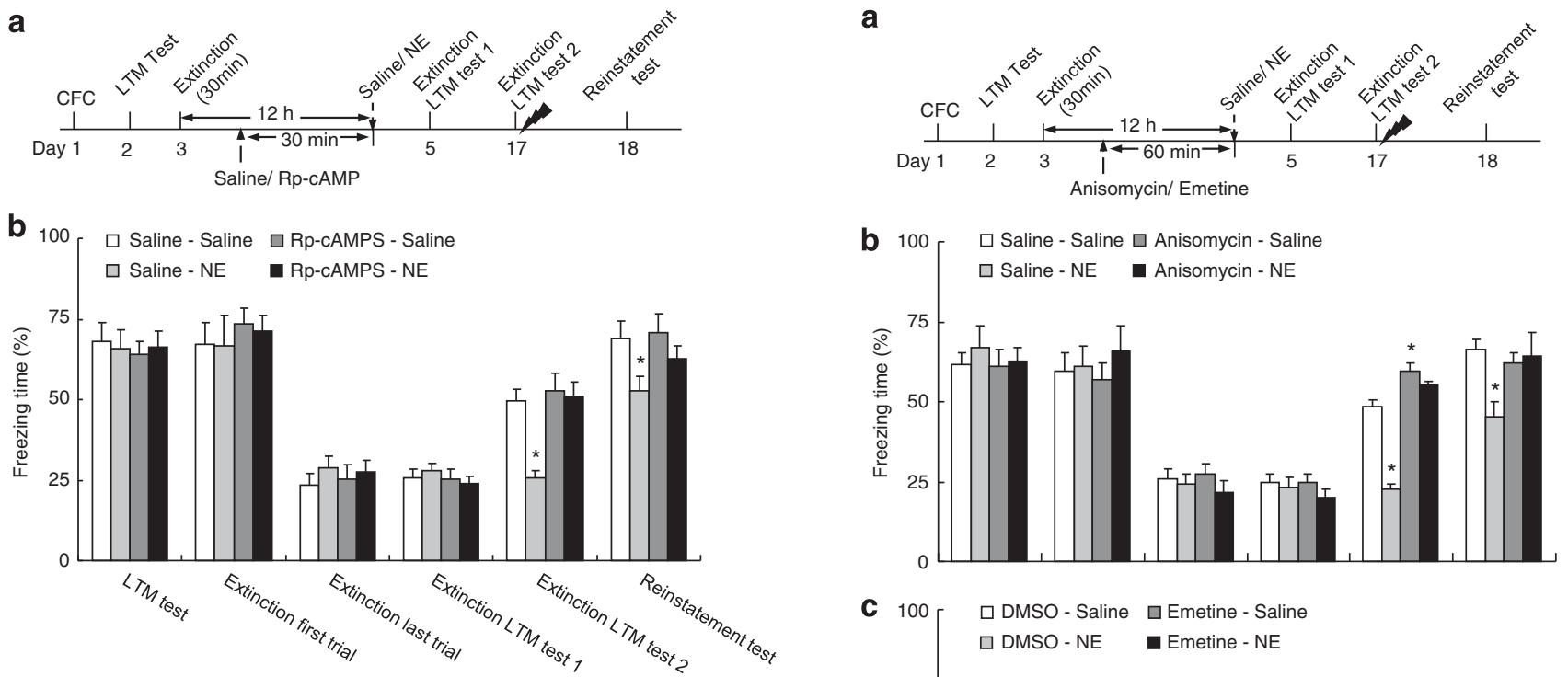

Figure 5 Rp-cAMPS blocked the NE-induced enhancement of extinction LTM persistence. (a) Timeline for this experiment. Norepinephrine $(I .0 \mu \mathrm{g} / \mu \mathrm{l})$ was microinfused into the CAI at I $2 \mathrm{~h}$ after extinction training, and the PKA inhibitor Rp-cAMPS was microinfused into the CAI 60 min before. Extinction LTM was tested 2 or 14 days later. After the extinction LTM test 2, a footshock ( $0.8 \mathrm{~mA}, \mathrm{I}$ ) was given, and fear reinstatement was tested I day later. (b) Norepinephrine microinfused into the CAI at $12 \mathrm{~h}$ after extinction enhanced the extinction LTM test 14 days after extinction and the reinstatement test $(p<0.05)$ that were blocked by Rp-cAMPS $(p<0.05)$. Rp-cAMPS treatment alone did not affect the extinction LTM test or reinstatement test (both $p>0.05$ ). The data are expressed as mean \pm SEM ( $n=8$ per group). ${ }^{*} P<0.05$ compared with Saline + Saline group.

induced by NE treatment, but also the late consolidation of extinction required new protein synthesis in the CA1 during the late phase after extinction.

\section{NE Activated the $\beta$-Receptor/PKA Signaling Pathway in the CAl during the Late Phase after Extinction}

In experiment 7 , we tested whether NE microinfusion into the CA1 during the late phase after extinction can activate the $\beta$-receptor/PKA signaling pathway. The rats were decapitated $13 \mathrm{~h}$ after extinction ( $1 \mathrm{~h}$ after NE infusion). The oneway ANOVA was conducted to analyze the effect of NE on the expression of membrane GluR1, cytosolic GluR1, PKA, Erk1/2, and CREB. The ANOVA showed a significant effect for membrane GluR1 expression $\left(\mathrm{F}_{4,39}=5.95, p<0.05\right)$. The post hoc analysis indicated that extinction training increased membrane GluR1 expression $(p<0.05$; Figure $7 b)$. The ANOVA revealed a significant effect of the level of pGluR1 (Ser 845, a site phosphorylated by PKA; $F_{4,39}=3.57$, $p<0.05)$ but not tGluR1 $\left(\mathrm{F}_{4,39}=0.25, p=0.91\right)$. The post hoc analysis indicated that pGluR1 was increased by NE that was blocked by propranolol and Rp-cAMPS $(p<0.05$; Figure $7 \mathrm{c}$ and $\mathrm{d})$. The ANOVA showed a significant effect for pPKA level $\left(\mathrm{F}_{4,39}=3.89, p<0.05\right)$ but not total PKA level $\left(\mathrm{F}_{4,39}=0.05, p=1.00\right)$. The post hoc analysis showed that NE treatment increased pPKA level that was blocked by propranolol and Rp-cAMPS (all $p<0.05$; Figure 7e and f). The ANOVA showed a significant effect for $\mathrm{pErk} 1 / 2$ level

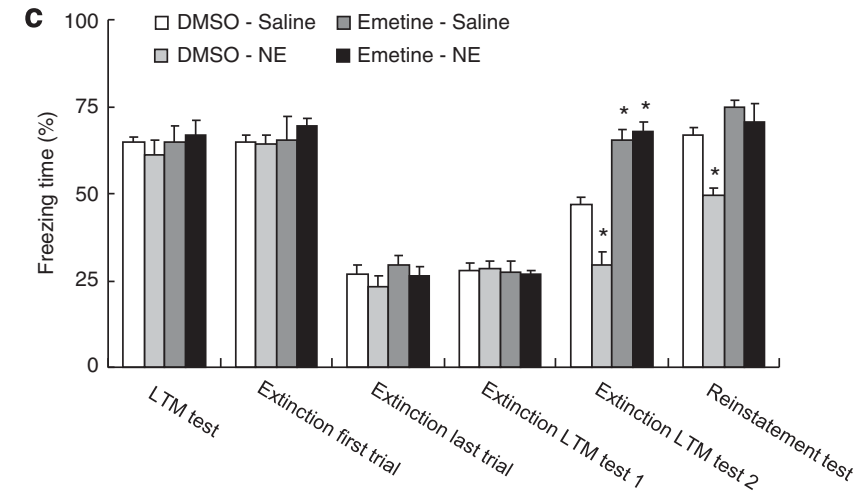

Figure 6 The persistence of extinction LTM requires late-phase protein synthesis in the CAI. (a) Timeline for this experiment. Norepinephrine $(1.0 \mu \mathrm{g} / \mu \mathrm{l})$ was microinfused into the $\mathrm{CAl}$ at $\mathrm{I} 2 \mathrm{~h}$ after extinction training, and the protein synthesis inhibitor anisomycin was microinfused into the CAI at I h before. Extinction LTM was tested 2 or 14 days later. After the extinction LTM test 2, a footshock (0.8 mA, I s) was given, and fear reinstatement was tested I day later. (b) Anisomycin blocked the effect of NE on extinction LTM test 2 and the reinstatement test $(p<0.05)$, suggesting that the effect of NE on extinction LTM required new protein synthesis $(p<0.05)$. Moreover, anisomycin alone significantly promoted fear recovery in extinction LTM test 2, suggesting a protein synthesisdependent process during the late phase after extinction $(p<0.05)$. (c) Emetine disrupted extinction LTM in test 2 and prevented the extinction-enhancing effect of NE $(p<0.05)$. The data are expressed as mean \pm SEM ( $n=8-10$ per group). ${ }^{*} P<0.05$ compared with Saline + Saline group or DMSO + Saline group.

$\left(\mathrm{F}_{4,39}=3.73, p<0.05\right)$ but not total Erk1/2 level $\left(\mathrm{F}_{4,39}=\right.$ $0.32, p=0.87)$. The post hoc analysis showed that extinction training increased pErk1/2 levels $(p<0.05)$ that were unaffected by NE, propranolol, and Rp-cAMPS (all $p>0.20$; Figure $7 \mathrm{~g}$ and $\mathrm{h}$ ). The ANOVA showed a significant effect for pCREB level $\left(\mathrm{F}_{4,39}=5.10, p<0.05\right)$ but not total CREB level $\left(\mathrm{F}_{4,39}=0.24, p=0.91\right)$. The post hoc analysis indicated that extinction training increased pCREB level $(p<0.05)$. NE treatment augmented the increase in PCREB level that was blocked by propranolol and Rp-cAMPS (all $p<0.05$; Figure $7 \mathrm{i}$ and $\mathrm{j}$ ). Altogether, these results indicate that $\mathrm{NE}$ in the CA1 during the late phase after extinction activated the PKA/CREB signaling pathway and increased membrane GluR1 trafficking. 
a

a<smiles>CC1CCCCC1C</smiles>

mem GluR1 $=-$

pGluR1 $=--=$

${ }_{\text {tGluR1 }}=-\infty$

PPKA

tPKA

pErk1/2

tErk $1 / 2$

PCREB

$\beta$-actin

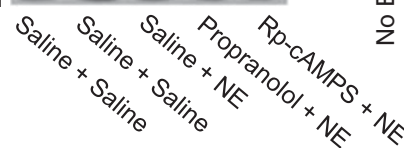

b

mem GluR1 / $\beta$-actin

$\square$ No Extinction $\square$ Extinction

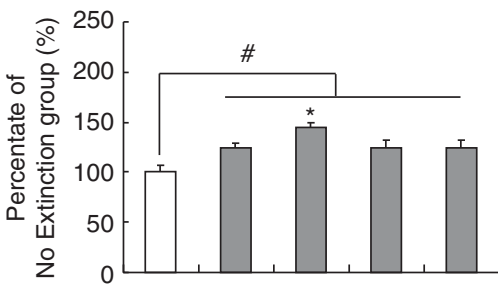

C
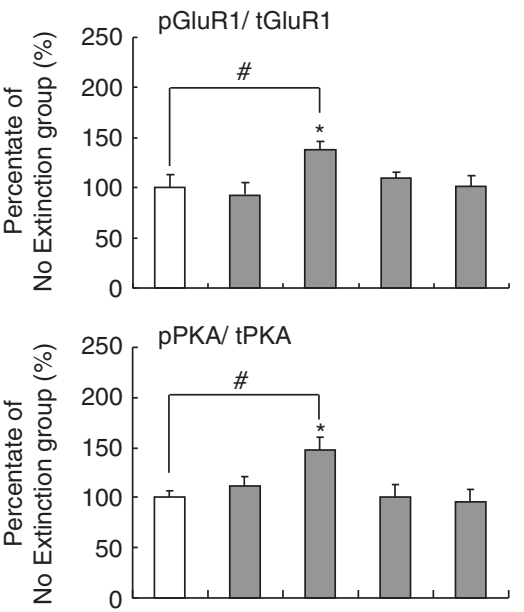

g

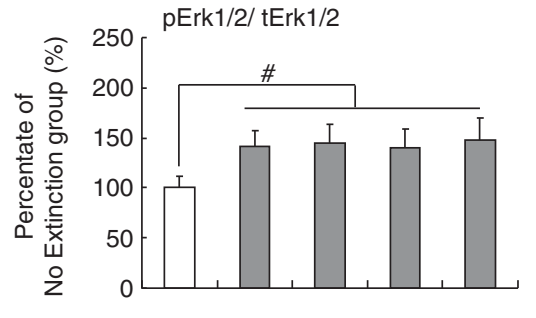

i

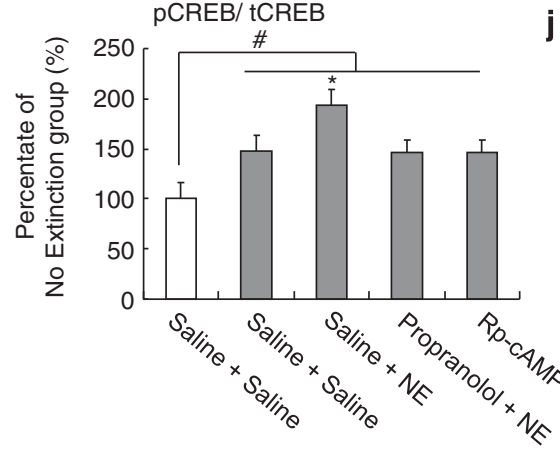

d tGluR1/ $\beta$-actin

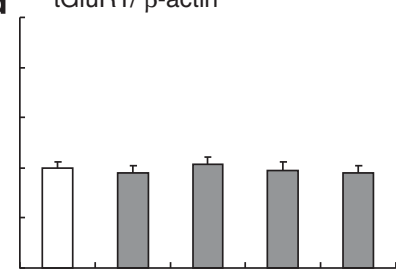

f $\mathrm{tPKA} / \beta$-actin

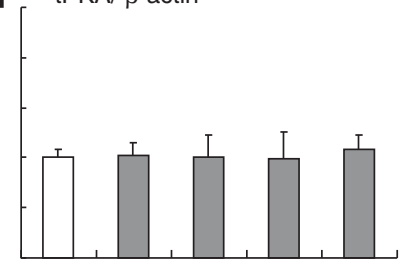

h tErk1/2/ $\beta$-actin

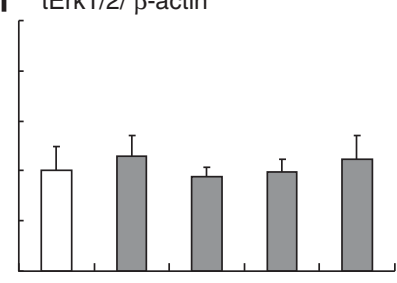

tCREB/ $\beta$-actin

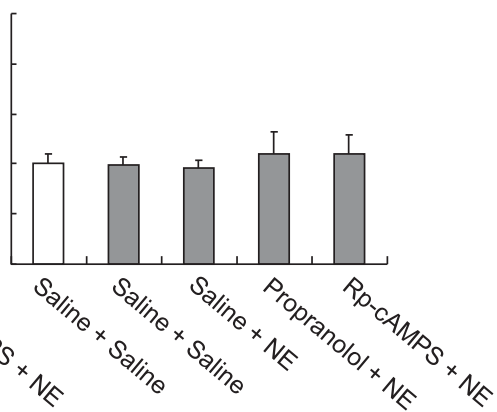

Figure 7 NE activated the $\beta$-receptor/PKA signaling pathway in the CAI during the late phase after extinction. (a) Representative western blots. (b) Extinction training significantly increased synaptosomal membrane GluRI expression in the CAI during the late phase of extinction $(p<0.05)$. NE augmented the alteration of GluRI that was blocked by propranolol and Rp-cAMPS (both $p<0.05$ ). (c) The level of pGluRI (Ser 845 ) in the CAI during the late phase of extinction was increased by NE that was prevented by propranolol and Rp-cAMPS (all $p<0.05$ ). (d) NE had no effect on total GluRI level $(p>0.05)$. (e) NE increased pPKA level in the CAI during the late phase of extinction that was blocked by propranolol and Rp-cAMPS (all $p<0.05)$. ( $f$ ) NE had no effect on total PKA level $(p>0.05)$. (g) pErkI/2 was only increased by extinction $(p<0.05)$ and unaffected by NE, propranolol, and Rp-cAMPS (all $p>0.05$ ). (h) Extinction did not affect total Erkl/2 level ( $p>0.05$ ). (i) NE promoted the increase in pCREB level in the CAI induced by extinction training $(p<0.05)$. Propranolol and Rp-cAMPS blocked the enhanced expression of $p C R E B$ (both $p<0.05)$ but had no effect on the increase in $p C R E B$ level induced by extinction training (both $p>0.05$ ). (j) NE had no effect on total CREB level ( $p>0.05$ ). The data are expressed as mean \pm SEM ( $n=8$ per group). ${ }^{*} P<0.05$ compared with Extinction + Saline + Saline group; ${ }^{\#} p<0.05$ compared with No Extinction + Saline + Saline group. pGluR I, phosphorylated GluRI; tGluRI, total GluRI; pPKA, phosphorylated PKA; tPKA, total PKA; pErkI/2, phosphorylated ErkI/2; tErkI/2, total PKA; pCREB, phosphorylated CREB; tCREB, total CREB. 


\section{DISCUSSION}

In the present study, we investigated the effect of $\mathrm{NE}$ treatment in the dorsal hippocampus during the late phase after extinction on extinguished fear memory. The results showed that microinfusion of NE into the CA1 area at $12 \mathrm{~h}$ after extinction enhanced the persistence of extinction LTM. Pretreatment with the $\beta$-receptor antagonist propranolol, PKA inhibitor, and protein synthesis inhibitor blocked the effect of late-phase NE treatment on the persistence of extinction LTM. The expressions of pPKA, pCREB, pGluR1, and membrane GluR1 but not pErk1/2 were increased by NE treatment that were blocked by pretreatment with propranolol or the PKA inhibitor in the CA1.

\section{Role of Hippocampal NE in the Persistence of Extinction LTM}

Extinguished fear will recover after a few weeks or months, suggesting that the extinction memory is too weak to be persistently stored. Several studies have investigated ways to enhance fear extinction (Abraham et al, 2012; Berlau and McGaugh, 2006; McGaugh et al, 1990; Mueller et al, 2008). Treatment with D-cycloserine, a partial agonist of NMDA receptors at the glycine modulatory site, enhanced extinction memory (Bouton et al, 2008; Mao et al, 2008; Walker et al, 2002). NE infusion into the infralimbic cortex improved extinction (Mueller et al, 2008), and this is consistent with the present results in which NE infusion into the CA1 immediately after extinction enhanced extinction consolidation. In addition, extinction has been used as a behavioral strategy to disrupt memory reconsolidation after retrieval in many types of memories (Costanzi et al, 2011; Flavell et al, 2011; Monfils et al, 2009; Xue et al, 2012). Nevertheless, even if these methods effectively promote extinction, none of them is specific to the persistence of extinction LTM.

Recent findings suggest that the persistence of long-term fear memory may require a late consolidation process that engages the activation of several molecules, synthesis of new proteins (Katche et al, 2013; Parfitt et al, 2012a, b), and circadian oscillation of the hippocampal cAMP/MAPK/ CREB transcriptional pathway (Eckel-Mahan et al, 2008). In the present study, using short extinction training, we found that NE treatment immediately after extinction promoted extinction LTM 2 days later, but NE treatment during the late phase after extinction promoted extinction LTM at 2 weeks but not 2 days later. These results indicate that NE treatment immediately after extinction promoted the formation of extinction LTM, but NE treatment during the late phase after extinction selectively enhanced the persistence of extinction LTM. Moreover, the extinction memory promoted by NE during the late phase could be reinstated, indicating that NE did not impair the original memory. NE treatment during the late phase after extinction also did not affect anxiety-like behavior or locomotor activity in rats. Considering that NE is an important molecule in the brain that affects the sleep/wake cycle, a potential interaction may exist between $\mathrm{NE}$ and sleep in the late consolidation process of extinction memory. In the inhibitory avoidance model, the late consolidation of LTM has been shown to be independent of the time of day when training is conducted
(Rossato et al, 2009). Nevertheless, the late consolidation of extinction memory may also be different from the original fear memory, and this needs to be investigated in future studies. Altogether, these results suggest that extinction engages a late consolidation process in the dorsal hippocampus that could be modulated by NE and specifically determines the persistence of extinction LTM.

After memory retrieval (short- or long-term retrieval), memory undergoes reconsolidation or extinction. The late reconsolidation process after retrieval in contextual fear memory has been demonstrated in at least two papers. The late reconsolidation of contextual fear memory requires protein synthesis in the BLA in mice (Nakayama et al, 2013). In our previous study, we demonstrated that cold water stress disrupted the late reconsolidation of contextual fear memory in rats (Yang et al, 2013). The hippocampus, which we focused on in the present study, is involved in both reconsolidation and extinction of contextual fear memory, but its role in these two processes is distinct. First, extinction suppresses the expression of fear, but short-term retrieval, which induces reconsolidation, has no such effect. Second, some opposing molecular mechanisms in the hippocampus underlie these two processes. For example, hippocampal $\mathrm{CREB}$ and $\mathrm{NF}-\kappa \mathrm{B}$ are activated by reconsolidation but not by extinction (de la Fuente et al, 2011; Mamiya et al, 2009), suggesting that some specific mechanism determines the memory process after retrieval.

\section{Mechanism That Underlies the Role of Hippocampal NE in the Persistence of Extinction LTM}

The enhancement of NE in the formation of fear memory and extinction has been extensively studied (McGaugh, 2004; Mueller and Cahill, 2010). As a stress hormone, NE promotes the stressful fear memory but does not appear to promote the nonstressful extinction memory. Moreover, treatment with the $\beta$-receptor antagonist propranolol alone did not affect extinction memory, suggesting that $\beta$ receptor activation is not involved in the consolidation of extinction (Cain et al, 2004; Rodriguez-Romaguera et al, 2009). Electrophysiological studies have demonstrated that $\beta$-receptor activation induced by NE could not induce hippocampal long-term potentiation but lowered the subthreshold stimulus response to long-term potentiation (Gelinas and Nguyen, 2005; Katsuki et al, 1997; Thomas et al, 1996; Tully et al, 2007). The enhancing effect of NE on extinction may be attributable to an influence on emotional arousal and attention (Mason, 1983) or the promotion of the intrinsic excitability of neurons responsible for extinction memory (Mueller and Cahill, 2010). Our results showed that propranolol blocked the enhanced persistence of extinction LTM induced by NE but had no effect when administered alone, indicating that $\beta$-receptor activation itself did not participate in the late consolidation of extinction memory.

The roles of PKA in the hippocampus in fear learning and extinction are distinct (Tronson et al, 2012). Fear conditioning activates the PKA signaling pathway that is significant inhibited by extinction (Isiegas et al, 2006; Li et al, 2009; Moita et al, 2002; Schafe et al, 1999). Genetic inhibition of PKA activity or pharmacological inhibition of the anchoring of PKA to A-kinase anchoring proteins facilitated extinction learning (Nijholt et al, 2008). Our 
results showed that the inhibition of PKA by Rp-cAMPS blocked the enhancing effect of NE on the persistence of extinction LTM and activation of the $\beta$-receptor-dependent PKA/CREB signaling pathway induced by NE. The cAMP analog Rp-cAMPs might also affect the activity of other cAMP substrates, including cyclic nucleotide-gated ion channels and cAMP hydrolases and cyclic nucleotide phosphodiesterases, two groups of molecules that interact with PKA (Moorthy et al, 2011; Rochais et al, 2004). Nevertheless, in the present study, we showed that the phosphorylation levels of both PKA and GluR1 (Ser 845, a site phosphorylated by PKA) were inhibited by Rp-cAMPs, suggesting that PKA is at least one of the main molecules that mediate the effect of NE on the persistence of extinction LTM. These results demonstrate that NE enhances the persistence of extinction LTM in a $\beta$-receptor/PKA/CREBdependent manner.

Protein kinase A is well known to regulate AMPAR trafficking to the postsynaptic membrane by phosphorylating the AMPAR (Crombag et al, 2008; Nayak et al, 1998). The $\beta_{2}$ receptor activation can stimulate the PKA-dependent phosphorylation of the GluR1 subunit of AMPAR associated with the $\beta_{2}$ receptor and then increase membrane GluR1 expression at postsynaptic sites (Joiner et al, 2010). Several studies have suggested that extinction that induces AMPAR trafficking is distinct in different brain areas. In the amygdala, surface GluR1 was upregulated by fear startle training, whereas D-cycloserine-facilitated extinction reversed this alteration (Mao et al, 2008). In the CA1 area of the hippocampus, both contextual fear learning and extinction increased GluR1 expression in mushroom-type spines (Matsuo et al, 2008). In the present study, we found that membrane GluR1 in the CA1 was also increased in the late consolidation of extinction memory that was augmented by NE. The increase in membrane GluR1 expression induced by NE was consistent with the elevation of pGluR1 (Ser 845) level that was blocked by propranolol and the PKA inhibitor, indicating that the increase in membrane GluR1 expression depended on PKA activation. Nevertheless, propranolol and the PKA inhibitor did not completely block the extinction-induced increase in membrane GluR1, suggesting other PKA-independent GluR1 trafficking mechanisms.

Although previous studies showed that the activation of PKA in the hippocampus is critical for the late consolidation of fear learning (Rossato et al, 2009), the present results demonstrated that the $\beta$-receptor/PKA signaling pathway does not underlie the late consolidation of extinction memory. Interestingly, the inhibition of protein synthesis during the late phase after extinction significantly reduced the persistence of extinction LTM, suggesting that $\beta$ receptor/PKA-independent new protein synthesis is needed for the late consolidation of extinction. Several molecules in the hippocampus have been shown to be involved in both fear conditioning and fear extinction, including cyclindependent kinase-5, protein kinase C, PKA, and ErK1/2 (Orsini and Maren, 2012; Tronson et al, 2012). Among these kinases, only ErK1/2 is activated in both processes (Atkins et al, 1998; Fischer et al, 2007; Irvine et al, 2005; Kimura et al, 2008; Tronson et al, 2012). Moreover, Erk1/2 is critical for the late consolidation of fear memory (Bekinschtein et al, 2007; Wan et al, 2010). In the present study, we found that Erk1/2 was activated in the late phase after extinction and was unaffected by NE. We infer that new protein synthesis in the dorsal hippocampus in the late consolidation of extinction memory may depend on the activation of Erk1/2, but this still needs further investigation.

\section{Concluding Remarks}

In summary, $\mathrm{NE}$ treatment in the dorsal hippocampus enhanced the late consolidation of extinction to promote the persistence of extinction LTM that was dependent on the activation of the $\beta$-receptor/PKA/CREB signaling pathway and membrane GluR1 trafficking. The specific modulation of the late consolidation of extinction may provide more precise strategies to selectively regulate the persistence of extinction LTM that may ultimately help optimize exposure therapy for posttraumatic stress disorder or anxiety-related disorders.

\section{FUNDING AND DISCLOSURE}

The authors declare no conflict of interest.

\section{ACKNOWLEDGEMENTS}

This work was supported in part by the Natural Science Foundation of China (nos. 81271489, 31230033, and 81221002).

\section{REFERENCES}

Abel T, Nguyen PV, Barad M, Deuel TA, Kandel ER, Bourtchouladze R (1997). Genetic demonstration of a role for PKA in the late phase of LTP and in hippocampus-based long-term memory. Cell 88: 615-626.

Abraham AD, Cunningham CL, Lattal KM (2012). Methylphenidate enhances extinction of contextual fear. Learn Mem 19: 67-72.

Atkins CM, Selcher JC, Petraitis JJ, Trzaskos JM, Sweatt JD (1998). The MAPK cascade is required for mammalian associative learning. Nat Neurosci 1: 602-609.

Bekinschtein P, Cammarota M, Igaz LM, Bevilaqua LR, Izquierdo I, Medina JH (2007). Persistence of long-term memory storage requires a late protein synthesis- and BDNF- dependent phase in the hippocampus. Neuron 53: 261-277.

Berlau DJ, McGaugh JL (2006). Enhancement of extinction memory consolidation: the role of the noradrenergic and GABAergic systems within the basolateral amygdala. Neurobiol Learn Mem 86: 123-132.

Bourtchouladze R, Abel T, Berman N, Gordon R, Lapidus K, Kandel ER (1998). Different training procedures recruit either one or two critical periods for contextual memory consolidation, each of which requires protein synthesis and PKA. Learn Mem 5: 365-374.

Bouton ME, Vurbic D, Woods AM (2008). D-cycloserine facilitates context-specific fear extinction learning. Neurobiol Learn Mem 90: 504-510.

Cain CK, Blouin AM, Barad M (2004). Adrenergic transmission facilitates extinction of conditional fear in mice. Learn Mem 11: 179-187.

Costanzi M, Cannas S, Saraulli D, Rossi-Arnaud C, Cestari V (2011). Extinction after retrieval: effects on the associative and nonassociative components of remote contextual fear memory. Learn Mem 18: 508-518. 
Crombag HS, Sutton JM, Takamiya K, Lee HK, Holland PC, Gallagher $\mathrm{M}$ et al (2008). A necessary role for GluR1 serine 831 phosphorylation in appetitive incentive learning. Behav Brain Res 191: 178-183.

Davis HP, Squire LR (1984). Protein synthesis and memory: a review. Psychol Bull 96: 518-559.

de Carvalho Myskiw J, Benetti F, Izquierdo I (2013). Behavioral tagging of extinction learning. Proc Natl Acad Sci USA 110: 1071-1076.

de la Fuente V, Freudenthal R, Romano A (2011). Reconsolidation or extinction: transcription factor switch in the determination of memory course after retrieval. J Neurosci 31: 5562-5573.

Eckel-Mahan KL, Phan T, Han S, Wang H, Chan GC, Scheiner ZS et al (2008). Circadian oscillation of hippocampal MAPK activity and cAmp: implications for memory persistence. Nat Neurosci 11: 1074-1082.

Fischer A, Radulovic M, Schrick C, Sananbenesi F, GodovacZimmermann J, Radulovic J (2007). Hippocampal Mek/Erk signaling mediates extinction of contextual freezing behavior. Neurobiol Learn Mem 87: 149-158.

Flavell CR, Barber DJ, Lee JL (2011). Behavioural memory reconsolidation of food and fear memories. Nat Commun 2: 504.

Gelinas JN, Nguyen PV (2005). Beta-adrenergic receptor activation facilitates induction of a protein synthesis-dependent late phase of long-term potentiation. J Neurosci 25: 3294-3303.

Haaker J, Gaburro S, Sah A, Gartmann N, Lonsdorf TB, Meier K et al (2013). Single dose of L-dopa makes extinction memories context-independent and prevents the return of fear. Proc Natl Acad Sci USA 110: E2428-E2436.

He YY, Xue YX, Wang JS, Fang Q, Liu JF, Xue LF et al (2011). PKMzeta maintains drug reward and aversion memory in the basolateral amygdala and extinction memory in the infralimbic cortex. Neuropsychopharmacology 36: 1972-1981.

Herry C, Ferraguti F, Singewald N, Letzkus JJ, Ehrlich I, Luthi A (2010). Neuronal circuits of fear extinction. Eur J Neurosci 31: 599-612.

Irvine EE, Vernon J, Giese KP (2005). AlphaCaMKII autophosphorylation contributes to rapid learning but is not necessary for memory. Nat Neurosci 8: 411-412.

Isiegas C, Park A, Kandel ER, Abel T, Lattal KM (2006). Transgenic inhibition of neuronal protein kinase A activity facilitates fear extinction. J Neurosci 26: 12700-12707.

Ji J, Maren S (2007). Hippocampal involvement in contextual modulation of fear extinction. Hippocampus 17: 749-758.

Joiner ML, Lise MF, Yuen EY, Kam AY, Zhang M, Hall DD et al (2010). Assembly of a beta2-adrenergic receptor-GluR1 signalling complex for localized cAMP signalling. EMBO J 29: 482-495.

Kandel ER (2012). The molecular biology of memory: cAMP, PKA, CRE, CREB-1, CREB-2, and CPEB. Mol Brain 5: 14.

Katche C, Bekinschtein P, Slipczuk L, Goldin A, Izquierdo IA, Cammarota $\mathrm{M}$ et al (2010). Delayed wave of c-Fos expression in the dorsal hippocampus involved specifically in persistence of long-term memory storage. Proc Natl Acad Sci USA 107: 349-354.

Katche C, Cammarota M, Medina JH (2013). Molecular signatures and mechanisms of long-lasting memory consolidation and storage. Neurobiol Learn Mem 106: 40-47.

Katsuki H, Izumi Y, Zorumski CF (1997). Noradrenergic regulation of synaptic plasticity in the hippocampal CA1 region. J Neurophysiol 77: 3013-3020.

Kimura R, Silva AJ, Ohno M (2008). Autophosphorylation of alphaCaMKII is differentially involved in new learning and unlearning mechanisms of memory extinction. Learn Mem 15: 837-843.

Kirtley A, Thomas KL (2010). The exclusive induction of extinction is gated by BDNF. Learn Mem 17: 612-619.

LaLumiere RT, Buen TV, McGaugh JL (2003). Post-training intrabasolateral amygdala infusions of norepinephrine enhance consolidation of memory for contextual fear conditioning. J Neurosci 23: 6754-6758.
Lee JL, Milton AL, Everitt BJ (2006). Reconsolidation and extinction of conditioned fear: inhibition and potentiation. J Neurosci 26: 10051-10056.

Li FQ, Xue YX, Wang JS, Fang Q, Li YQ, Zhu WL et al (2010). Basolateral amygdala cdk5 activity mediates consolidation and reconsolidation of memories for cocaine cues. J Neurosci 30: 10351-10359.

Li Y, Li H, Liu X, Bao G, Tao Y, Wu Z et al (2009). Regulation of amygdalar PKA by beta-arrestin-2/phosphodiesterase-4 complex is critical for fear conditioning. Proc Natl Acad Sci USA 106: 21918-21923.

Li YQ, Li FQ, Wang XY, Wu P, Zhao M, Xu CM et al (2008). Central amygdala extracellular signal-regulated kinase signaling pathway is critical to incubation of opiate craving. J Neurosci 28: $13248-13257$.

Lima RH, Rossato JI, Furini CR, Bevilaqua LR, Izquierdo I, Cammarota M (2009). Infusion of protein synthesis inhibitors in the entorhinal cortex blocks consolidation but not reconsolidation of object recognition memory. Neurobiol Learn Mem 91: 466-472.

Lu L, Hope BT, Dempsey J, Liu SY, Bossert JM, Shaham Y (2005). Central amygdala ERK signaling pathway is critical to incubation of cocaine craving. Nat Neurosci 8: 212-219.

Lubin FD, Sweatt JD (2007). The IkappaB kinase regulates chromatin structure during reconsolidation of conditioned fear memories. Neuron 55: 942-957.

Mamiya N, Fukushima H, Suzuki A, Matsuyama Z, Homma S, Frankland PW et al (2009). Brain region-specific gene expression activation required for reconsolidation and extinction of contextual fear memory. J Neurosci 29: 402-413.

Mao SC, Lin HC, Gean PW (2008). Augmentation of fear extinction by $\mathrm{D}$-cycloserine is blocked by proteasome inhibitors. Neuropsychopharmacology 33: 3085-3095.

Maren S, Phan KL, Liberzon I (2013). The contextual brain: implications for fear conditioning, extinction and psychopathology. Nat Rev Neurosci 14: 417-428.

Mason ST (1983). The neurochemistry and pharmacology of extinction behavior. Neurosci Biobehav Rev 7: 325-347.

Matsuo N, Reijmers L, Mayford M (2008). Spine-type-specific recruitment of newly synthesized AMPA receptors with learning. Science 319: 1104-1107.

McGaugh JL (2000). Memory-a century of consolidation. Science 287: $248-251$.

McGaugh JL (2004). The amygdala modulates the consolidation of memories of emotionally arousing experiences. Annu Rev Neurosci 27: 1-28.

McGaugh JL, Castellano C, Brioni J (1990). Picrotoxin enhances latent extinction of conditioned fear. Behav Neurosci 104: 264-267.

Medina JH, Bekinschtein P, Cammarota M, Izquierdo I (2008). Do memories consolidate to persist or do they persist to consolidate? Behav Brain Res 192: 61-69.

Milad MR, Quirk GJ (2002). Neurons in medial prefrontal cortex signal memory for fear extinction. Nature 420: 70-74.

Moita MA, Lamprecht R, Nader K, LeDoux JE (2002). A-kinase anchoring proteins in amygdala are involved in auditory fear memory. Nat Neurosci 5: 837-838.

Moncada D, Ballarini F, Martinez MC, Frey JU, Viola H (2011). Identification of transmitter systems and learning tag molecules involved in behavioral tagging during memory formation. Proc Natl Acad Sci USA 108: 12931-12936.

Monfils MH, Cowansage KK, Klann E, LeDoux JE (2009). Extinction-reconsolidation boundaries: key to persistent attenuation of fear memories. Science 324: 951-955.

Moorthy BS, Gao Y, Anand GS (2011). Phosphodiesterases catalyze hydrolysis of cAMP-bound to regulatory subunit of protein kinase A and mediate signal termination. Mol Cell Proteomics 10: 002295. 
Morgan MA, LeDoux JE (1999). Contribution of ventrolateral prefrontal cortex to the acquisition and extinction of conditioned fear in rats. Neurobiol Learn Mem 72: 244-251.

Mueller D, Cahill SP (2010). Noradrenergic modulation of extinction learning and exposure therapy. Behav Brain Res 208: 1-11.

Mueller D, Porter JT, Quirk GJ (2008). Noradrenergic signaling in infralimbic cortex increases cell excitability and strengthens memory for fear extinction. J Neurosci 28: 369-375.

Mueller GE, Pilzecker A (1900). Experimentelle beitrage zur lehre vom gedachtniss. Zeitschrift fuer Psychologie 1: 1-288.

Nakayama D, Yamasaki Y, Matsuki N, Nomura H (2013). Postretrieval late process contributes to persistence of reactivated fear memory. Learn Mem 20: 307-310.

Nayak A, Zastrow DJ, Lickteig R, Zahniser NR, Browning MD (1998). Maintenance of late-phase LTP is accompanied by PKA-dependent increase in AMPA receptor synthesis. Nature 394: 680-683.

Nijholt IM, Ostroveanu A, Scheper WA, Penke B, Luiten PG, Van der Zee EA et al (2008). Inhibition of PKA anchoring to A-kinase anchoring proteins impairs consolidation and facilitates extinction of contextual fear memories. Neurobiol Learn Mem 90: 223-229.

Orsini CA, Maren S (2012). Neural and cellular mechanisms of fear and extinction memory formation. Neurosci Biobehav Rev 36: 1773-1802.

Parfitt GM, Barbosa AK, Campos RC, Koth AP, Barros DM (2012a). Moderate stress enhances memory persistence: are adrenergic mechanisms involved? Behav Neurosci 126: 729-734.

Parfitt GM, Campos RC, Barbosa AK, Koth AP, Barros DM (2012b). Participation of hippocampal cholinergic system in memory persistence for inhibitory avoidance in rats. Neurobiol Learn Mem 97: 183-188.

Pavlov IP (1927). Conditioned Reflexes. Oxford University Press: London.

Paxinos G, Watson C (2005). The Rat Brain in Stereotaxic Coordinates. 5 edn. Elsevier Academic Press: Amsterdam.

Quirk GJ (2002). Memory for extinction of conditioned fear is long-lasting and persists following spontaneous recovery. Learn Mem 9: 402-407.

Quirk GJ, Garcia R, Gonzalez-Lima F (2006). Prefrontal mechanisms in extinction of conditioned fear. Biol Psychiatry 60: 337-343.

Quirk GJ, Russo GK, Barron JL, Lebron K (2000). The role of ventromedial prefrontal cortex in the recovery of extinguished fear. J Neurosci 20: 6225-6231.

Ren ZY, Liu MM, Xue YX, Ding ZB, Xue LF, Zhai SD et al (2013). A critical role for protein degradation in the nucleus accumbens core in cocaine reward memory. Neuropsychopharmacology 38: 778-790.

Rochais F, Vandecasteele G, Lefebvre F, Lugnier C, Lum H, Mazet JL et al (2004). Negative feedback exerted by cAMP-dependent protein kinase and cAMP phosphodiesterase on subsarcolemmal cAMP signals in intact cardiac myocytes: an in vivo study using adenovirus-mediated expression of CNG channels. J Biol Chem 279: 52095-52105.

Rodriguez-Romaguera J, Sotres-Bayon F, Mueller D, Quirk GJ (2009). Systemic propranolol acts centrally to reduce conditioned fear in rats without impairing extinction. Biol Psychiatry 65: 887-892.

Rossato JI, Bevilaqua LR, Izquierdo I, Medina JH, Cammarota M (2009). Dopamine controls persistence of long-term memory storage. Science 325: 1017-1020.

Schafe GE, LeDoux JE (2000). Memory consolidation of auditory pavlovian fear conditioning requires protein synthesis and protein kinase A in the amygdala. J Neurosci 20: RC96.

Schafe GE, Nadel NV, Sullivan GM, Harris A, LeDoux JE (1999). Memory consolidation for contextual and auditory fear conditioning is dependent on protein synthesis, PKA, and MAP kinase. Learn Mem 6: 97-110.

Seeds NW, Gilman AG (1971). Norepinephrine stinulated increase of cyclic AMP levels in developing mouse brain cell cultures. Science 174: 292.
Shi HS, Zhu WL, Liu JF, Luo YX, Si JJ, Wang SJ et al (2012). PI3K/ Akt signaling pathway in the basolateral amygdala mediates the rapid antidepressant-like effects of trefoil factor 3. Neuropsychopharmacology 37: 2671-2683.

Sotres-Bayon F, Sierra-Mercado D, Pardilla-Delgado E, Quirk GJ (2012). Gating of fear in prelimbic cortex by hippocampal and amygdala inputs. Neuron 76: 804-812.

Squire LR, Davis HP (1981). The pharmacology of memory: a neurobiological perspective. Annu Rev Pharmacol Toxicol 21: 323-356.

Sun LL, Zhang Y, Liu JF, Wang J, Zhu WL, Zhao LY et al (2013). Role of melanin-concentrating hormone in the nucleus accumbens shell in rats behaviourally sensitized to methamphetamine. Int J Neuropsychopharmacol 16: 1767-1780.

Suo L, Zhao L, Si J, Liu J, Zhu W, Chai B et al (2013). Predictable chronic mild stress in adolescence increases resilience in adulthood. Neuropsychopharmacology 38: 1387-1400.

Szapiro G, Vianna MR, McGaugh JL, Medina JH, Izquierdo I (2003). The role of NMDA glutamate receptors, PKA, MAPK, and CAMKII in the hippocampus in extinction of conditioned fear. Hippocampus 13: 53-58.

Thomas MJ, Moody TD, Makhinson M, O’Dell TJ (1996). Activitydependent beta-adrenergic modulation of low frequency stimulation induced LTP in the hippocampal CA1 region. Neuron 17: 475-482.

Tronson NC, Corcoran KA, Jovasevic V, Radulovic J (2012). Fear conditioning and extinction: emotional states encoded by distinct signaling pathways. Trends Neurosci 35: 145-155.

Tully K, Li Y, Tsvetkov E, Bolshakov VY (2007). Norepinephrine enables the induction of associative long-term potentiation at thalamo-amygdala synapses. Proc Natl Acad Sci U S A 104: 14146-14150.

Vianna MR, Szapiro G, McGaugh JL, Medina JH, Izquierdo I (2001). Retrieval of memory for fear-motivated training initiates extinction requiring protein synthesis in the rat hippocampus. Proc Natl Acad Sci USA 98: 12251-12254.

Vitolo OV, Sant'Angelo A, Costanzo V, Battaglia F, Arancio O, Shelanski M (2002). Amyloid beta -peptide inhibition of the PKA/CREB pathway and long-term potentiation: reversibility by drugs that enhance cAMP signaling. Proc Natl Acad Sci USA 99: 13217-13221.

Walker DL, Ressler KJ, Lu KT, Davis M (2002). Facilitation of conditioned fear extinction by systemic administration or intraamygdala infusions of D-cycloserine as assessed with fearpotentiated startle in rats. J Neurosci 22: 2343-2351.

Wan H, Mackay B, Iqbal H, Naskar S, Kemenes G (2010). Delayed intrinsic activation of an NMDA-independent CaM-kinase II in a critical time window is necessary for late consolidation of an associative memory. J Neurosci 30: 56-63.

Wang X, Luo YX, He YY, Li FQ, Shi HS, Xue LF et al (2010). Nucleus accumbens core mammalian target of rapamycin signaling pathway is critical for cue-induced reinstatement of cocaine seeking in rats. J Neurosci 30: 12632-12641.

Winocur G, Gilbert M (1984). The hippocampus, context, and information processing. Behav Neural Biol 40: 27-43.

Xue YX, Luo YX, Wu P, Shi HS, Xue LF, Chen C et al (2012). A memory retrieval-extinction procedure to prevent drug craving and relapse. Science 336: 241-245.

Yang C, Liu JF, Chai BS, Fang Q, Chai N, Zhao LY et al (2013). Stress within a restricted time window selectively affects the persistence of long-term memory. PLoS One 8: e59075.

Zhang L, Ouyang M, Ganellin CR, Thomas SA (2013). The slow afterhyperpolarization: a target of beta1-adrenergic signaling in hippocampus-dependent memory retrieval. J Neurosci 33: 5006-5016.

Zhu WL, Shi HS, Wang SJ, Xu CM, Jiang WG, Wang X et al (2012). Increased Cdk5/p35 activity in the dentate gyrus mediates depressive-like behaviour in rats. Int J Neuropsychopharmacol 15: 795-809. 